\title{
SEASONAL PERFORMANCE AND ENERGY COSTS OF OIL OR GAS-FIRED BOILERS AND FURNACES
}

\author{
A.L. BerLad, H.C. LIN, J. BATEY, \\ F.J. Salzano, W.S. Yu, R.J. Hoppe, and T. Allen
}

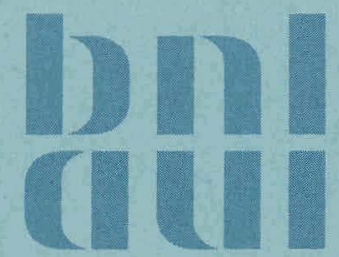

March 1977

DEPARTMENT OF APPLIED SCIENCE

BROOKHAVEN NATIONAL LABORATORY

ASSOCIATED UNIVERSITIES, INC.

UNDER CONTRACT NO. EY-76-C-02-0010 WIIH IHE

UNITED STATES ENERGY RESEARCH AND DEVELOPMENT ADMINISTRATION 


\section{DISCLAIMER}

This report was prepared as an account of work sponsored by an agency of the United States Government. Neither the United States Government nor any agency Thereof, nor any of their employees, makes any warranty, express or implied, or assumes any legal liability or responsibility for the accuracy, completeness, or usefulness of any information, apparatus, product, or process disclosed, or represents that its use would not infringe privately owned rights. Reference herein to any specific commercial product, process, or service by trade name, trademark, manufacturer, or otherwise does not necessarily constitute or imply its endorsement, recommendation, or favoring by the United States Government or any agency thereof. The views and opinions of authors expressed herein do not necessarily state or reflect those of the United States Government or any agency thereof. 


\section{DISCLAIMER}

Portions of this document may be illegible in electronic image products. Images are produced from the best available original document. 
BNL 50647

(Energy Conservation-Buildings

and Community Systems - TID-4500)

\title{
SEASONAL PERFORMANCE AND ENERGY COSTS OF 'OIL OR GAS-FIRED BOILERS AND FURNACES
}

\author{
A.L. BERLAD, ${ }^{*}$ H.C. LIN, ${ }^{*}$ J. BateY, \\ F.J. Salzano, W.S. Yu, R.J. Hoppe, and T. Allen
}

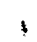

March 1977

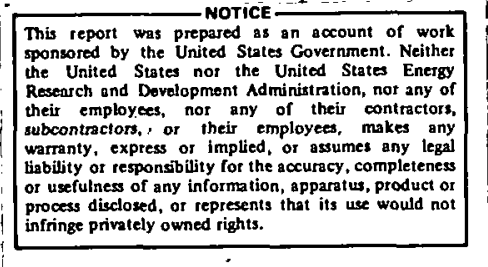

*College of Engineering and Applied Sciences, State University of New York, Stony Brook, N.Y. 11794

\section{DEPARTMENT OF APPLIED SCIENCE}

BROOKHAVEN NATIONAL LABORATORY UPTON, NEW YORK 11973 


\section{N O T I C E}

This report was prepared as an account of work sponsored by the United Stales Finvernment. Neither the. United States nor the United States Energy Research and Development Administration, nor any of their employees, nor any of their contractors, subcontractors, or their employees, makes any warranty, express or implied, or assumes any legal liability or responsibility for the accuracy, completeness or usefulness of any information, apparatus, product or procese disclosed, or represents that its use would not infringe privately owned rights.

Printed in the United States of America Available from

National Technical Information Service

U.S. Department of Commerce

5285 Port Royal Road

Springfield, VA 22161

Price: Printed Copy $\$ 4.50$; Microfiche $\$ 3.00$

June 1977

580 copies 
$\underline{\text { Page }}$

Abstract . . . . . . . . . . . . . . . . vi v

I. Introduction and Background . . . . . . . . . . . . . . 1

II. Enthalpy Balances and Seasonal Usage of Fuel . . . . . . 5

III. Mode of Application . . . . . . . . . . . . . . . 9

IV. Some Applications to Oil-Fired Boilers . . . . . . . . . 12

V. Comparison with an Air-to-Air Heat Pump . . . . . . . 16

VI. Concluding Remarks . . . . . . . . . . . . . . . 18

VII. Nomenclature . . . . . . . . . . . . . . . 20

Tables

Table 1 - Annual Usage of Number 2 Fuel Oil Per Year (gallons/year) - Boiler [A] . . 22

Table 2 - Annual Usage of Number 2 Fuel Oil Per Year (gallons/year) - Boiler [B] • . . 22

Table 3 - Annual Usage of Number 2 Fuel oil Per Year (gallons/year) - Boiler [C] . . 23

Table 4 - Seasonal Performance Factor (SPF) for Boiler [A]. . . . . . . . . . 23

Table 5 - Seasonal Performance Factor (SPF) for Boiler [B] . . . . . . . . . . 24

Table 6 - Seasunal Performance Factor (EPF) for Boiler [C] . . . . . . . . . . 24

Table 7 - Normalized Annual Consumption of Number 2 Fuel Oil for Various Conditions. . . . . . . . . . . 25

Tablc 8 - Annual Electrical Usage (kwt-hr) Boiler [A]... . . . . . . . . 25

Table 9 - Annual Electrical Usage (kwt-hr) Boiler [B]... . . . . . . . . 26

Table 10 - Annual Electrical Usage (kwt-hr) Boiler [C]... . . . . . . . . 26 
Table of Contents (Cont'd)

Page

Table 11 - Annual Operating Costs - Boiler [A] . . 27

Table 12 - Annual Operating Costs - Boiler [B] . . 27

Table 13 - Annual Operating Costs - Boiler [C] . - 28

Table 14 - Measured COP (Overall) for a High Quality Air-to-Air Heat Pump Sized to Heat a 50,000 Btuh Design Load . ... 28

Table 15 - Annual Performance of an Air-to-Air Pump . . . . . . . . . . . . . 29

Figures

Figure 1 - Steady State Efficiency vs. Firing Rate for a Steel Fire-Tube Boiler. . . 30

Figure $2 \mathrm{a}$ - Steady State Efficiency (잉 vs. Boiler Outlet Temperature ( $O F)$ for Boiler [A] .............. 31

Figure 2b - Steady State Efficiency ( $(\%)$ vs. Boiler Outlet Temperature (OF) [úr Builer [B] . . . . . . . . . . .

Figure 2c - Steady State Efficiency (\%) vs. Boilcr outlet Temperature ( $\left.{ }^{\circ} \mathrm{F}\right)$ for Boiler [C] . . . . . . . . .

Figure 3a - Cycle Efficiency $\left(n_{C}\right)$ vs. Burner Fractional "On" Time ( 8 ) for Boiler [A] . . . . . . . . . . 32

Figure $3 b$ - Cycle Efficiency $\left(n_{c}\right)$ vs. Burner Fractional "On" Time (\%) for Boiler [B] . . . . . . . . . .

Figure 3c - Cycle Efficiency $\left(n_{C}\right)$ vs. Burner Fractional. "On" Time (8) for Boiler [C] ............ . 33

References . . . . . . . . . . . . . . . 34 Appendix

Part A - Evaluation of Seasonal Performance of an Oil or Gas-Fired Boiler/Furnace. . . . 35 
Table of Contents (Cont'd)

page

$\begin{aligned} \text { Part B - } & \text { Evaluation of Seasonal Performance } \\ & \text { of an Air-to-Air Heat Pump . . . . . . . } 36 \\ \text { Part C - } & \text { Ten-Year Hourly Average Weather Data } \\ & \text { for Three Representative Climates. } \\ & \text { Eight-Month Heating Season and Twelve- } \\ & \text { Month Heating Season . . . . . . . . . . } 38 \\ \text { Part D - } & \text { Program Printout . . . . . . . . . . . }{ }^{4} 33\end{aligned}$ 


\section{Abstract}

The seasonal operating cost of a small oil or gas-fired boiler or furnace depends upon the intrinsic merits of the device itself, the appropriateness of its capacity and cycle characteristics to the imposed load conditions, the weather characteristics and heat loss characteristics of the building being heated, and the control philosophy employed. The current study provides the bases for comparing quantitatively the seasonal operating costs of various specific space heating and/or domestic hot water systems, as influenced by the device specifics and device interaction with the space conditioned system that it serves. The resulting formalism is applied to various space heating systems. Quantitative cost comparisons are presented. 


\section{INTRODUCTION AND BACKGROUND}

The cost effective performance of an oil or gas-fired boiler or furnace depends upon a number of factors. Some of these factors are characteristics solely of the boiler/furnace under consideration. ${ }^{1}$ other factors pertain to the coupling mechanisms (e.g., water lines, air ducts, etc.) between energy conversion device and the conditioned space it serves. Still other factors pertain to the merits of the "sizing" of the energy conversion device and its appropriateness when measured against the enthalpy flow demands imposed by the structure it is required to serve. 2,3

One may assess the effectiveness of a structure's design and operating strategy in making optimum use of a given boiler/furnace system. Analyses with these emphases are given elsewhere. 1,3 The purpose of this analysis is to provide the bases for comparing the seasonal operating costs of various specific space heating and/or domestic hot water systems, as influenced by the device specifics and device interaction with the space conditioned system it serves.

A given space conditioning device can have its intrinsic merits evaluated in a laboratory. Thus, for example, an oil-fired boiler's efficiency is generally characterized in terms of its steady state efficiency, $n_{s}$, and its cycle efficiency curve. Studies have shown $n_{s}$ to be a function of a number of operating parameters. It is generally found that $\eta_{s}$ increases with reduced firing rate and that $\eta_{s}$ increases with reduced boiler temperature (FIgures 1 and 2). The cycle efficiency curve (cycle efficiency vs. fractional burner "ON TIME") is Found to be well defined, once the various operating 
parameters (including the ON/OFF control philosophy and a characteristic ON TIME) are fixed. Cycle efficiency curves shown for three different oil-fired boilers, subject to an operating philosophy and a characteristic ON TIME which is typical for (frame construction) residential dwellings (Figure 3). We have previously shown ${ }^{3}$ that high mass (masonry construction) structures, insulated exterior to the high mass shell, will provide very long ON TIMES and cycle efficiency values very close to unity.

Accordingly, devices which display very high $\eta_{s}$ values and $\eta_{c}$ curves which stay close to unity, even as the fractional ON TIME falls are considered to be of high merit (high efficiency). Based on laboratory measurements, then, the intrinsic figures of merit of the space heating device (boiler) are determinable.

The seasonal performance of such a well-studied device is not determinable on the basis of laboratory measurements alone. Seasonal performance is ultimately measured, by the consumer, in terms of operating costs for the installed device, serving a specific house, in a specific city, during a specific heating season, subject to the infinitude of house variables (house size, shape, degree of insulation, wind exposure, solar exposure, airtightness, internal heat sources, venting, sight topography, landscaping effects, etc.) as well as variables pertaining to the wisdom of the heating systems' Installation (line losses, design firing rate, use/nonuse of conditioned air for combustion, etc.) and servicing (cleanliness of boiler, fuel nozzle cleanliness, etc.). One can assess the performance of a laboratory tested device (as well as a nontested one) in a specific situation (specific house, installation, 
city, heating season, subject to the vagaries of a specific family's operation of their home) by recording the total seasonal energy usage (and the associated costs) for space heating. A knowledge of the boiler's efficiency characteristics is not needed to make such an in the field determination.

In this work we apply laboratory derived efficiency measurements to

1. estimate the expected seasonal performance (cost) of a properly installed (and serviced) space heating device-when coupled to a structure whose standard thermal features are to be characterized.

2. compare the effects of device efficiencies ( $\eta_{s}$ and $\eta_{c}$ ) on the expected seasonal performace (cost).

As noted earlier, the expected in-the-field seasonal performance can be influenced by a very large number of factors.

In-the-field determination of seasonal costs vary from installation-to-installation and require total energy usage (and cost) data, not necessarily efficiency data. The intrinsic efficiencies of a given oil-fired boiler may be central to the seasonal performance of a given installation, but seasonal performance pertains to the entire system properties (house with all its subsystems and interactions) and not to the space-heating source alone.

It is thus clear that any analytic model designed to evaluate the seasonal performance of a space-heating system must include certain features. Without these features adequately specified, the system itself will be found to be inadequately specified. These are found to be the system (house) characteristics necessary to specify 
the seasonal operational history (and energy usage history) of the space heating device. It is the space heating device's seasonal operating (and energy usage) history which determines seasonal cost. In this work, we include only those system (house plus subsystem plus interactions) characteristics which are "necessary." Our definition of "necessary" embraces the following:

1. A specified design heat load for a frame structure.

2. An hourly temperature history (and heating load) for the structure.

3. Specifics of the domestic hot water load that the system (house) is to require.

4. The intrinsic merits and the operating characteristics of the oil-fired device that serves the overall system (the structure)

The above four features are "necessary" to any adequate analytic model. One may also consider one or more of the very many constraints which (in an in-the-field installation) may serve to degrade "seasonal performance." As detailed earlier, these include duct/line losses, unwise house venting, unwise boiler installation (e.g., use of conditioned air for combustion and off-cycle stack venting), etc.... If we were to include these features, however, we would be including unnecessary features. Their inclusion would obfuscate the purposes of the analysis. Our purpose is to provide an assessment of the seasonal performance of a specific system (house) employing a wisely installed and properly operated, specific oil-fired boiler under specified seasonal load conditions. 
Thus, the myriad additional interactions which are capable of degrading a system's performance are taken to be "unnecessary." Wise installation and proper maintenance and operation would eliminate them. Their inclusion would detract from our central purposes-to rationally evaluate and compare the seasonal performances of a specific characteristic system (house), as determined by necessary feature 4, the intrinsic merits of the device--properly and wisely installed, operated and maintained.

Before proceeding with this analysis, we recognize the existence and importance of other studies ${ }^{4,5}$ whose purposes are to identify and evaluate the many ways in which unwise installations and operational constraints can (unnecessarily) degrade seasonal performance. Those studies have helped us understand the costs incurred by unnecessarily degraded systems.

\section{ENTHALPY BALANCES AND SEASONAL USAGE OF FUEL}

The seasonal performance of a given boiler/furnace-heated system (structure with all its subsystems) is measured in terms of the seasonal heating energy costs for the syslem. We may use this scasonal performance (cost) as an installed figure of merit for the boiler/furnace subsystem if the installation is fully comparable to that which applies to the determination of an installed figure of merit for some competitive system (boiler, furnace, heat pump, etc.). Without standardization of this kind, comparison of two figures of merit (e.g., for two competing space heating devices) would have little meaning. 
To derive such a figure of merit, we consider first the energy delivery rate of a boiler/furnace of interest--as it interacts with the hourly demands of the heated structure it is designed to serve.

$$
\dot{\mathrm{m}}_{\mathrm{f}} \eta_{\mathrm{c}} \eta_{\mathrm{s}} \Delta_{\mathrm{c}}+\sum_{\mu} \mathrm{s}_{\mu}=\mathrm{L}+\mathrm{H}_{\mathrm{O}} \text {, for } \mathrm{T}_{\mathrm{c}}<\mathrm{T}^{*}
$$

Symbol definitions appear in a nomenclature section.

In equation ( 1 ), the hourly load, $L$, does not include all the source and sink terms that may be other than linear functions of the dimensionless temperature difference, $T$. These terms appear in the summation, $\sum S_{\mu}$, and may include such diverse sources as the heating output of kitchen appliances, electric lighting, the energy output of living occupants, etc. $\sum s_{\mu}$ may also include such diverse sinks as venting of conditioned air by unwisely installed boilers/ furnaces, by externally vented clothes dryers, bathroom and kitchen vents, etc.

In order to provide a figure of merit for a given installed piece of equipment, unencumbered by unnecessary building characteristics, we consider the heating device of interest to interact with a building system for which $\sum S_{\mu} \equiv 0$. Equation (1) may then be rewritten:

$$
\dot{\mathrm{m}}_{\mathrm{f}} n_{c} n_{s} \Delta_{c}=\mathcal{X}_{\mathrm{d}} \mathrm{T}+\mathrm{II}_{\mathrm{o}}, \text { for } \mathrm{T}_{\mathrm{c}}<\mathrm{T}^{*}
$$

Corresponding steady state conditions give

$$
\dot{m}_{f, d} n_{s} \Delta_{c}=\left(x_{d}+I_{o}\right) \alpha
$$


The "overfiring ratio" generally has a value, $\alpha>1$, reflecting considerations of domestic hot water supply. It has been shown elsewhere 2,4 that $\alpha$ should be taken as small as possible, in order to assure optimum overall efficiency $(\bar{n})$ values.

Note that for commonly encountered ${ }^{2,3}$ operating cycles (frame structures) one can correlate $n_{c}$ as a function of the ratio $\left(\stackrel{\mathrm{m}}{f}_{f} / \stackrel{\mathrm{m}}{f, d}_{\mathrm{d}}\right)$. Thus, for a given characteristic ON TIME (cycle characteristic)

$$
\eta_{\mathrm{c}}=\phi\left(\stackrel{\mathrm{m}}{\mathrm{f}}_{\mathrm{f}} / \stackrel{\mathrm{m}}{\mathrm{f}, \mathrm{d}}\right)
$$

where the functional dependence of equation (3) is determined in the laboratory for any given piece of apparatus. Inasmuch as ${ }^{2,3}$

$$
\bar{n}=n_{c} n_{s}
$$

it follows that $\dot{\mathrm{m}}_{\mathrm{f}}$ enters equation (1) in a nonlinear fashion. Combining (2a) and (2b) gives for $\left(T_{C}<T^{*}\right)$ :

$$
\dot{\mathrm{m}}_{f}=\left[\frac{\dot{\mathrm{m}}_{\mathrm{f}, \mathrm{d}}}{\alpha \eta_{c}}-\frac{\mathrm{H}_{\mathrm{O}}}{\Delta_{c} \bar{\eta}}\right]\left[\frac{\mathrm{T}^{*}-\mathrm{T}_{c}}{\bar{T}^{*}-\mathrm{T}_{\mathrm{d}}}\right]+\frac{\mathrm{H}_{O}}{\Delta_{c}^{\bar{\eta}}}
$$

Thus, during any given hour characterized by $T_{c, i}$, the actual fuel mass flow rate is

$$
\dot{\mathrm{m}}_{\mathrm{f}, i}=\left[\frac{\dot{\mathrm{m}}_{\mathrm{f}, \mathrm{d}}}{\alpha \eta_{c, i}}-\frac{\mathrm{H}_{0}}{\Delta_{c} \bar{\eta}_{i}}\right]\left[\frac{\mathrm{T}^{*}-\mathrm{T}_{c, 1}}{\mathrm{~T}^{\star}-\mathrm{T}_{\mathrm{d}}}\right]+\frac{\mathrm{H}_{0}}{\Delta_{c} \bar{\eta}_{i}}
$$

Given $\mathrm{n}_{i}$ hours per season which have a characteristic temperature, $\mathrm{T}_{C, i}$ (where $\mathrm{T}_{\mathrm{C}, \mathrm{i}}<\mathrm{T}^{*}$ for all $\mathrm{i}$ ) we may write the resulting total 
fuel usage

$$
\dot{m}_{f, i} n_{i}=\left[\frac{\dot{m}_{f, d}}{\alpha n_{c, i}}-\frac{H_{0}}{\Delta_{c} \bar{\eta}_{i}}\right]\left[\frac{T^{*}-T_{c, i}}{T^{*}-T_{d}}\right] n_{i}+\left(H_{o} n_{i}\right) /\left(\Delta_{c} \bar{\eta}_{i}\right)
$$

Then, summing over $T_{c ; i}<T^{*}$ values, the total annual heating season fuel usage is obtained

$$
\begin{aligned}
\mathrm{M}_{1}=\sum_{i} \dot{\mathrm{m}}_{f, i} \mathrm{n}_{i}=\sum_{i} & \left\{\left[\frac{\dot{\mathrm{m}}_{\mathrm{f}, \mathrm{d}}}{\alpha \dot{\mathrm{n}}_{c, i}}-\frac{\mathrm{H}_{0}}{\Delta_{c} \bar{\eta}_{i}}\right]\left[\frac{\mathrm{T}^{*}-\mathrm{T}_{c, i}}{\mathrm{~T}^{*}-\mathrm{T}_{\mathrm{d}}}\right] \mathrm{n}_{i}\right\} \\
& +\sum_{i}\left(\mathrm{H}_{\mathrm{o}} \mathrm{n}_{i}\right) /\left(\Delta_{c} \bar{n}_{i}\right)
\end{aligned}
$$

In order to obtain the corresponding total annual fuel usage $M_{2}$, for the nonheating season, we note that for $T_{c} \geq T^{*}$

$$
\tilde{n}_{f}^{*} \bar{n} \Delta_{C}=H_{O}
$$

where $\bar{n}^{*}$ is a nonlinear function of $\dot{m}_{f}$. Thus, the total mass of fuel used for domestic hot water (nonheating season) is given by

$$
M_{2}=\frac{\mathrm{H}_{o} \mathrm{n}^{*}}{\eta_{\mathrm{c}}^{*} n_{s}{ }^{\Delta}}
$$

Correspondingly, for a "perfect" system $\left(n_{C}=\eta_{S}=1\right)$

$$
\left(M_{2}\right)_{p}=\frac{H_{o} n^{*}}{\Delta_{c}}=M_{2} \eta_{C}^{*} \eta_{s}
$$

The total mass of fuel used during the year is given by

$$
\mathrm{M}=\mathrm{M}_{1}+\mathrm{M}_{2}
$$


where the specific cost data may be used to calculate (from equation (12)) the seasonal cost for fuel oil. To this cost must be added the seasonal costs of all electrically energized auxiliary equipment (oil pump, air fan, water circulator).

We may also define a Seasonal Performance Factor (SPF) in terms of $\left(M / M_{p}\right)$, where $M_{p}$ is the fuel mass that would have been consumed by a (physically unobtainable) "perfect" system $(\bar{n}=1)$. To find the value of

$$
M_{p}=\left(M_{1}\right)_{p}+\left(M_{2}\right)_{p}
$$

We note that $\left(M_{1}\right)_{p}$ and $\left(M_{2}\right)_{p}$ are obtained from equations $(8),(10)$, and (II).

The Seasonal Performance Factor may be taken as a "figure of mexit." We may then choose to define it as follows:

$$
(\mathrm{SPF}) \equiv \frac{\mathrm{M}_{\mathrm{P}}}{\mathrm{M}}
$$

We will find that the (SPF) so defined is not needed in order to calculate seasonal operating costs for energy usage. Rather, the (SPF) so defined may be used as a measure of the direct fossil fuel usage efficiency--not including the costs that derive from the use of electrically energized components.

III. MODE OF APPLICATION.

Seasonal performance (cost) is calculated directly from a knowledge of the fossil fuel (and electrical) energy consumed by the 
installed space heating device, interacting with the characteristic structure it serves. Laboratory-determined values of $\left(n_{s}\right)$ and $\left(n_{c}\right)$ are employed in the calculation of seasonal performance of several oil-fired boiler systems. Such application may proceed, calculationally, in a number of ways. Consider, for example, that equation (6) can be rewritten as

$$
\left(n_{c, i}\right)\left(\frac{\dot{m}_{f, i}}{\dot{m}_{f, d}}\right)=\left[\left(\frac{1}{\alpha}\right)-\frac{H_{o}}{\Delta_{c^{n} s^{\dot{m}_{f, d}}}}\right]\left[\frac{T^{*}-T_{C, i}}{T^{*}-T_{d}}\right]+\left[\frac{H_{o}}{\Delta_{c} s^{\dot{m}_{f, d}}}\right]
$$

or

$$
\Lambda_{i}=Q_{1}
$$

where $\left(\Lambda_{i}\right)$ is the left-hand side of equation (15). $\left(\boldsymbol{Q}_{i}\right)$ is the right-hand side of equation (15). For an installed piece of equipment, we generally have the following information: The design heat load, $\chi_{\mathrm{d}}$; the average hourly domestic hot water to be provided, $\mathrm{H}_{\mathrm{O}}$; the heat of combustion of the fuel, $\Delta_{c}$; the (laboratory ariscrtained) value of the steady state efficiency, $n_{s} ;$ and the firing rate ("nozzle size" in hourly mass flow rate), $\dot{m}_{f, d^{*}}$ Accordinyly, we calculate the "overfiring ratio," $\alpha$, from equation (2).

for a given outside temperature, $T_{c, i}$, a given (design) interior temperature $T^{*}$ and a given (design) outside temperature, $T$ ' we find that the right-hand side of equation (15), $\mathbb{Q}_{i}$, is fully specified and calculable. The cycle efficiency, $n_{c}$ ' is found to be a simple monotonic function of the burner fractional on time $\left(\dot{\mathrm{m}}_{\mathrm{f}} / \dot{\mathrm{m}}_{\mathrm{f}, \mathrm{d}}\right)$. Accordingly, one may use laboratory determined curves 
(such as those shown in Figure 3) of $\left(n_{c}\right)$ vs. $\left(\dot{m}_{f} / \dot{m}_{f, d}\right)$ to determine the unique product $\left(n_{c, i}\right)\left(\dot{m}_{f, i} / \dot{m}_{f, d}\right)$ which satisfies the left-hand side of equation (15),

$$
\Lambda_{i}=\left(n_{c, i}\right)\left(\dot{m}_{f, i} / \dot{m}_{f, d}\right)
$$

Thus, for any given exterior hourly temperature, $T_{i}$, the corresponding cycle efficiency, $\left(\eta_{c, i}\right)$, and the hourly mass flow rate, $\left(\dot{m}_{f, i}\right)$ are easily found.

Equation (15) is similarly applied for each possible hourly temperature of interest, $T_{c, i}=\left(T_{d}\right),\left(T_{d}+1\right),\left(T_{d}+2\right), \ldots\left(T^{*}-1\right)$. This yields a table of values of $\left(\eta_{c, i}\right)$ and $\left(\dot{m}_{f, i} / m_{f, d}\right)$ as a function of outside temperature.

Examination of the weather data for any given locality, during any given heating season, permits the tabulation of a chart of $\left(n_{i}\right)$ values--the number of seasonal heating hours that correspond to each value of the outside temperature, $T_{c, i}$. Thus, all necessary hourly data are available for calculation of the summation given by equation (8)--the total mass of fuel used during the heating season, $M_{1}$. To find the total mass of fuel used over a twelve-month period (for both heating and domestic hot water) one adds the total mass of fuel used for domestic hot water during the nonheating season, $M_{2}$. Thus equation (12) yields the total twelve-month usage of fossil fuel for heating and domestic hot water.

The total annual entigy costs for the syctom are given by

$$
c_{t}=M C_{m}+c_{e}\left\{\left[\sum_{i}\left(\frac{\dot{m}_{f, i}}{\dot{n}_{f, d}}\right) n_{i} \omega_{H}\right]+\left[\left(\frac{\dot{m}_{f}^{*}}{\dot{m}_{f, d}}\right) n * \omega_{s}\right]\right\}
$$


where the first term on the right-hand side of (16) gives the annual fossil fuel costs and the final cluster of terms gives the annual electrical costs (pumps, fans, circulators, etc.).

\section{SOME APPLICATIONS TO OIL-FIRED BOILERS}

The seasonal performance formulation may be applied to any fossil fuel-fired system, once we specify

- hourly (design) firing rate

- design heat load for the structure (conditioned space)

- the structure's weather experience during the period of interest $\left(n_{i}\right.$ vs. $\left.T_{c, i}\right)$

- the design domestic hot water load

- design indoor temperature

- the (laboratory determined value of) steady state efficiency

- the (laboratory determined curve of) cycle efficiency vs. fractional on time, for à given operaliund mude.

The formulation has been applicd to the eases of lhiee different boiler systems, each serving a structure for which $\boldsymbol{\chi}_{\mathrm{d}}=50,000$ Btuh. Hourly weather data were taken ${ }^{6}$ for a ten-year (hour-by-hour) average for the Metropolitan New York City area. In all cases, propper installation, service and maintenance are assumed to apply. Further discussion of these calculations is qiven in the Appendix. The three boiler systems studied are each commercially available units. In order of decreasing performance, they are designated Lo be builers [A], [B], and [C], respectively. Figures (2) and (3) give the steady state and cycle efficiency data employed in this 
calculation. Data for Figures (2) and (3) were determined in the laboratories of Brookhaven National Laboratory.

Tables (1)-(3) give the total annual fossil fuel usage (in gallons of number 2 fuel oil per year) for a number of overfiring ratios and domestic hot water loads. We note that $\alpha=1$ usage corresponds to number 2 fuel oil firing rates which are lower than $0.75 \mathrm{gals} / \mathrm{hr}$. Rates below $0.75 \mathrm{gals} / \mathrm{hr}$ are smaller than those characteristically encountered in the field, although equipment currently under test at BNL can be utilized at these low firing rates. All cases of $\alpha=2$ or $\alpha=3$ correspond to firing rates greater than $0.75 \mathrm{gals} / \mathrm{hr}$.

It is clear that Boiler [A] is better than Boiler [B], which is in turn better than Boiler [C]. One may assess the seasonal efficiency of each of these boilers (based on the efficiency in the direct use of fossil fuel energy alone) by determining the appropriate Seasonal Performance Factors. As noted earlier, such SPF values are not needed in order to calculate seasonal costs (from equation (16)), which must include electrical energy costs as well. Nevertheless, such SPF values are useful bases for comparison of the installed seasonal efficiencies (based on oil usage only) of oil-fired boilers. Seasonal Performance Factors for Boilers [A], [B], and [C] are shown in Tables (4)-(6). Summer only SPF values are distressingly low. Nevertheless, these low (summer only) values have only a modest effect on the annual SPF (overall twelve-month period). This result derived directly from the fact that summer, highly inefficient fuel oil usage consumes only a small fraction of the (overall) annual fuel oil usage. 
One may also compare the possible range of seasonal direct fossil fuel usage rates by normalizing the values of Tables (1)-(3) in terms of the minimum value (993 gals of number 2 fuel oil) obtained. Table 7 gives the Direct Annual Fossil Fuel Usage Ratios for Boilers $[A],[B]$, and [C].

Examination of the tabulated results, Tables (1)-(7), shows that the performance of Boiler [A] benefits both from its very fine $\left(n_{\dot{s}}\right)$ value as well as from its very desirable $\left(n_{c}\right)$ vs. $\left(\dot{m}_{f} / \dot{m}_{f, d}\right)$ curve (Figure 3). Also, for currently available firing rates Boiler [A] can provide seasonal efficiencies in the range of $(76.6 \%$ to $78.5 \%)$.

Contrasting to the best performance of [A], we find lhat Boiler [C] may have seasonal efficiencies that are substantially lower.

It is important to recall that all calculations presented are based on the assumption of wise and proper installation, maintenance, servicing, and cleaning of all equipment.

As has been noted elsewhere, $1,2,4,5$ 1mproper/unwise inctallation, sizing, operation, maintenance and servicing can degrade the performance of any space conditioning system--including the ones studied here.

In order to calculate the annual energy operating costs for each of these boilers, one must know

1. the number of kilowatt-hours of electrical energy used by each device; when its oil pump, circulator, fan, etc. is operating

2. the annual number of hours during which each such component operates, for each device 
3. the cost of electrical energy, per killowatt hour

4. the cost of number 2 fuel oil, per gallon.

Item (2) is derivable from the analysis previously presented. Consequently, item (1) is directly calculable. Items (3) and (4) may vary, according to locale, customer usage pattern, and with the other numerous factors which affect the pricing of electrical energy. Tables (8)-(10) show the electrical energy usage patterns. for Boilers [A], [B], and [C] respectively. Although variations in installations may be expected, the following typical power consumption rates are assumed. A circulator is assumed to operate at 0.200 Kwatts. The air fan plus oil pump are taken to operate at 0.200 Kwatts. Calculated results are shown in Tables $(8)-(10)$.

Total annual operating costs (number 2 fuel oil plus electrical energy) are directly calculable from the data of Tables (1)-(3) and (8)-(10), inclusive. Cost data for oil and electrical energy are required. In recent years, such cost data hve changed rapidly. Nevertheless, using figures that appear to be currently applicable to central and eastern Long Island, New York, we derive the cost - data of Figure (11)-(13) inclusive. It is seen that Boiler [A] sustains very modest cost increases due to increased overfiring ratios. This is largely due to the excellent $\left(\eta_{C}\right)$ characteristics of this boiler (Figure 3). Boilers [B] and [C] annually use about the same electrical energy as does [A]. These latter two boilers, due to their lower $\left(n_{c}\right)$ and $\left(n_{s}\right)$ values are more costly to operate. 


\section{COMPARISON WITH AN AIR-TO-AIR HEAT PUMP}

The application of the seasonal performance formulation for oil-fired boilers (previous section) was made for a 50,000 Btuh space heating load. The formulation is easily applicable to other constraints of fuel type, firing rate, heating load, weather, and climate. Such applications are currently under way and will be reported at a later time.

Recent in situ tests of a given high quality air-to-air heat pump have been carried out by the National Bureau of standards 5 for a 50,000 Btuh space heating load. The heat pump in question was sized to meet the design heating load (an unusual feature), thereby permitting only minimal use of ordinary resistance heating for heat pump output augmentation at temperatures below the balance point. This strategy does increase cycle losses at high operating temperatures, however.

NBS measured performance data are shown in Table 14 (from referencie 5).

The data of reference (5) may be used directly with the weather data for Metropolitan New York (see previous sections) to deduce a seasonal performance for a 50,000 Btuh heat load. In order that the so-calculated results be comparable to those previously obtained for oil-fired boilers, we again assume proper installation, maintenance, and operation. Thus, for example, duct losses, etc. are considered not to exist. Results of this calculation are shown in Table 15. Further discussion of these calculations is given in the Appendix. It is assumed that resistance 
heat (COP of unity) is employed to supply domestic hot water. Costs are illustrated for $\$ 0.03$ per kwt-hr to $\$ 0.05$ per kwt-hr. Costs per kwt-hr may vary substantially with regional conditions. At this writing, costs for heat pump users in central and eastern Long Island, New York are approximately $\$ 0.035$ per kwt-hr.

It is hoped that more extensive heat pump operating data will be forthcoming from the various national laboratories at an early date, thereby permitting a more comprehensive characterization of estimated annual performances.

Comparison of these limited data for oil-fired boilers and the specific heat pump installation examined indicates that.'

1. Resistance heated domestic hot water degrades the seasonal COP for an air-to-air heat pump (Tables 14 and 15).

2. An oil-fired boiler employed to also furnish domestic hot water has its seasonal performance less strikingly effected (Tables $1-13$ ).

3. The best of the three oil-fired units (Boiler [A]) providing $120 \mathrm{gals} /$ day of domestic hot water has seasonal energy costs of $\$ 682$ (for an overfiring ratio of $\alpha=2$ ).

4. The heat pump system studied, providing 120 gals/day of domestic hot water (same hour-by-hour heating load as Boiler [A]) and using electrical energy at \$0.035 per kwthr has seasonal heating energy costs of $\$ 1092$. Kwt-hr costs of electrical energy have been found to vary substantially with regional location, with time, and with the "user class" of the electric utility customer. This appears to be less true for users of oil. 


\section{CONCLUDING REMARKS}

All space conditioning devices have intrinsic merits/deficiencies which govern their operating ability to deliver heating/cooling services efficiently to the conditioned spaces that they are asked to serve. Over and above the intrinsic merits of a space conditioning device, seasonal performance analyses must include the essential characteristics of the conditioned space so served. These essential characteristics include the structure's design heating load, the detailed weather (exterior) conditions of interest, and the operating (control) philosophy for the overall system. Taken together with the energy conversion capacity of the device, as well as its steady state and cyclic figures of merịt, these systems characteristics permit the calculation of the seasonal performance of the overall system.

In order to assure an equitable basis for comparison of the performance of various competing devices, it is found useful to omit consideration of the myriad performance degradations that derive from improper/unwise installation, maintenance, servicing, and operation of any device of interest.

For the case of oil or gas-fired boilers (or furnaces), the formulation given in this report can be employed, in conjunction with laboratory-determined boiler/furnace efficiency data to determine seasonal performance (seasonal energy usage) and seasonal costs. For the case of a given boiler, $\left(n_{S}\right)$ and $\left(n_{c}\right)$ values can be determined in the laboratory. Once the other parametric variables are specified (e.g., design firing rate, seasonal weather 
history, domestic hot water usage, design heat load, etc.) the calculation is straightforward. Some details of such calculations are given in the Appendix.

Application of the formulation is illustrated for three oilfired boiler systems of varying intrinsic merits. The basic efficiency data for the calculation were obtained at Brookhaven National Laboratory. For purposes of an equitable comparison with another space heating device, National Bureau of Standards data on the Coefficient of Performance of a high quality air-to-air heat pump were employed (together with the identical assumptions regarding the conditioned space and weather conditions). Results of the comparison of the four systems studied (the oil-fired boilers plus one heat pump) are presented.

The formulation is being currently utilized in a more extensive study of a range of devices and operating conditions. 


\section{NOMENCLATURE}

$\mathrm{C}_{\mathrm{e}}$ - Hourly operating costs of the electrical components of a fossil-fuel-fired space heating (and domestic hot water) system (dollars/hour).

$C_{m}$ - Specific fossil fuel costs (dollars per pound of fuel).

$c_{t}$ - Annual energy costs for the system (dollars per year).

$\mathrm{H}_{\mathrm{O}}$ - Domestic hot water.load (Btu/hr).

I - Heat loss (load) for conditioned space nf a characteristic structure (Btu/hr).

d - Design heat loss (Joar) for conditioned space of a characteristic structure (Btu/hr).

$\dot{\mathrm{m}}_{\mathrm{f}}$ - Mass flow rate of fuel, actual $(1 \mathrm{bs} / \mathrm{hr})$.

$\dot{\mathrm{m}}_{\mathrm{f}, \mathrm{d}}$ - Mass flow rate of fuel, design $(\mathrm{lbs} / \mathrm{hr})$.

$\dot{m}_{f}^{*} \quad-$ Mass flow rate of fuel during the nonheating season, actual (lbs/hr).

M - Total mass of fuel used during the year (lbs).

$M_{1}$ - Total mass of fuel used during the heating season ( $1 \mathrm{bs}$ ).

$M_{2} \quad$ - Total mass of fuel used during the nonheating season (lbs).

Mp - 'l'atal mass of fucl that would be user during the heating season by a (preffect) system for which all $n$ values dite unity (lbs).

$M_{2 p}$ - Total mass of fuel that would be used during the nonheating season by d (perfect) system tor which all $n$ values are unity (lbs).

$n_{i} \quad-\quad N u m h e r$ nf hours in the ycar having a vialallesistle outdoor temperature, $\mathrm{T}_{\mathrm{Ci}}$ ' during the heating season $\left(T_{c, i}<T^{*}\right)$.

$\mathrm{n}^{*}$ - Total number of hours in the nonheating season $\left(\mathrm{T}_{\mathrm{C}} \geq \mathrm{T}^{*}\right)$

$S_{\mu} \quad-$ Heat source or sink, of the $\mu^{\text {th }}$ kind, in the conditioned space (Btu/hr).

$\mathrm{T}=$ Temperature $\left(\mathrm{F}^{\prime}\right)$. 
$\mathrm{T}_{\mathrm{C}} \quad$ - Characteristic outside temperature $\left({ }^{\circ} \mathrm{R}\right)$. $\mathrm{T}_{\mathrm{C}, \mathrm{i}}-\mathrm{Characteristic}_{\left({ }^{\circ}\right) \text {. }}$ outside temperature of the $i^{\text {th }}$ value

$\mathrm{T}_{\mathrm{d}}$ - Outside temperature used for design heat loss calculations for the conditioned space $\left({ }_{R}\right)$.

$T^{*} \quad-$ Temperature of the conditioned space $\left({ }^{\circ} R\right)$.

$\alpha \quad$ - The overfiring ratio.

$\Delta_{c} \quad$ - Heat of combustion of fuel (Btu/lb)

$\bar{\eta}$ - Overall efficiency of the boiler/furnace

$\bar{\eta}^{*} \quad-$ Overall efficiency during the nonheating season

$n_{C}^{*} \quad-$ Cycle efficiency

$\bar{n}_{i} \quad$ - Cycle efficiency during the nonheating season.

$n_{s}$ - Overall efficiency when the outside characteristic temperature has a value $\mathrm{T}_{\mathrm{c}, \mathrm{i}}$.

$T$ - Dimensionless temperature difference for the conditioned space, $\left[\left(\mathrm{T}^{*}-\mathrm{T}_{\mathrm{C}}\right) /\left(\mathrm{T}^{*}-\mathrm{T}_{\mathrm{d}}\right)\right]$

$\phi \quad$ - An experimentally determined function that relates the cycle efficiency to the actual (and design) firing rates of a boiler/furnace, for a given characteristic cycle.

$\omega_{H} \quad$ - Heating season electrical power requirements for fossilfuel-fired system during on mode.

$\omega_{S} \quad$ - Summer season electrical power requirements for fossilfuel-fired system during on mode. 
Table 1, Boiler [A]

Annual Usage of Number 2 Fuel Oil Per Year (gallons/year). N.Y. Metropolitan Area. Ten-year hourly weather data; 8-month heating plus 12 month domestic hot water. For $\alpha=1, \dot{\mathrm{m}}_{\mathrm{f}, \mathrm{d}}<0.75 \mathrm{gal} / \mathrm{hr}$. For $\alpha=2$ and $\alpha=3, \dot{\mathrm{m}}_{\mathrm{f}, \mathrm{d}}>0.75 \mathrm{gal} / \mathrm{hr}$.

\begin{tabular}{|lcccc|}
\hline$H_{0}$ & 0 & $\begin{array}{c}40 \\
\text { gal/day }\end{array}$ & $\begin{array}{c}80 \\
\text { gal/day }\end{array}$ & $\begin{array}{c}120 \\
\text { gal/day }\end{array}$ \\
\hline 1 & 993 & 1127 & 1224 & 1328 \\
2 & 1021 & 1214 & 1292 & 1380 \\
3 & 1064 & 1317 & 1399 & 1480 \\
\hline
\end{tabular}

Table 2, Boiler [B]

Annual Usage of Number 2 Fuel oil. Per Year (gallons/year). N.Y. Metropolitan Area. Ten year hourly weather data: 8 month heating plus 12 month domestic hot water. For $\alpha=1, \dot{\mathrm{m}}_{\dot{f}, \mathrm{~d}}<0.75 \mathrm{gal} / \mathrm{hr}$. For $\alpha=2$ and $\alpha=3, \mathfrak{h}_{f, d}>0.75 \mathrm{gal} / \mathrm{hr}$.

\begin{tabular}{|lcccc|}
\hline $\mathrm{H}_{\mathrm{O}}$ & 0 & $\begin{array}{c}40 \\
\text { gal/day }\end{array}$ & $\begin{array}{c}80 \\
\text { gal/day }\end{array}$ & $\begin{array}{c}120 \\
\text { gal/day }\end{array}$ \\
\hline 1 & 1105 & 1307 & 1401 & 1522 \\
2 & 1209 & 1493 & 1620 & 1723 \\
3 & 1326 & 1670 & 1834 & 1960 \\
\hline
\end{tabular}


Table 3, Boiler [C]

Annual Usage of Number 2 Fuel oil Per Year (gallons/year). N.Y. Metropolitan Area. Ten year hourly weather data; 8 month heating plus 12 month domestic hot water. For $\alpha=1, \mathfrak{m}_{f, d}<0.75 \mathrm{gal} / \mathrm{hr}$. For $\alpha=2$ and $\alpha=3, \dot{\mathrm{m}}_{\mathrm{f}, \mathrm{d}}>0.75 \mathrm{gal} / \mathrm{hr}$.

\begin{tabular}{|ccccc|}
\hline $\mathrm{H}_{\mathrm{O}}$ & 0 & $\begin{array}{c}40 \\
\text { gal/day }\end{array}$ & $\begin{array}{c}80 \\
\text { gal/day }\end{array}$ & $\begin{array}{c}120 \\
\text { gal/day }\end{array}$ \\
\hline 1 & 1192 & 1399 & 1508 & 1611 \\
2 & 1283 & 1557 & 1704 & 1822 \\
3 & 1399 & 1722 & 1902 & 2047 \\
\hline
\end{tabular}

Table 4, Boiler [A]

Seasonal Performance Factor (SPF) for Boiler [A]. N.Y. Metropolitan Area. Ten year hourly weather data.

\begin{tabular}{|cccccc|}
\hline $\mathrm{H}_{\mathrm{O}}$ & 0 & $\begin{array}{c}40 \\
\text { gal/day }\end{array}$ & $\begin{array}{c}80 \\
\text { gal/day }\end{array}$ & $\begin{array}{c}120 \\
\text { gal/day }\end{array}$ & Season \\
\hline 1 & .8069 & .7869 & .7938 & .7963 & 12 months \\
& -0 & .4513 & .6213 & .6787 & $\begin{array}{c}\text { Summer } \\
\text { Only }\end{array}$ \\
\hline 2 & .7845 & .7302 & .7522 & .7663 & 12 months \\
& -0. & .2372 & .4406 & .5749 & $\begin{array}{c}\text { Summer } \\
\text { Only }\end{array}$ \\
\hline 3 & .7529 & .6729 & .6948 & .7146 & 12 months \\
&.-1607 & .3035 & .4304 & $\begin{array}{c}\text { Summer } \\
\text { Only }\end{array}$ \\
\hline
\end{tabular}


Table 5, Boiler [B]

Seasonal Performance Factor (SPF) for Boiler [B].

\begin{tabular}{|cccccc|}
\hline $\mathrm{H}_{\mathrm{O}}$ & 0 & $\begin{array}{c}40 \\
\text { gal/day }\end{array}$ & $\begin{array}{c}80 \\
\text { gal/day }\end{array}$ & $\begin{array}{c}120 \\
\text { gal/day }\end{array}$ & Season \\
\hline 1 & .7247 & .6785 & .6939 & .7069 & 12 months \\
& --- & .2308 & .3999 & .5181 & $\begin{array}{c}\text { Summer } \\
\text { Only }\end{array}$ \\
\hline 2 & .6435 & .5937 & .5999 & .6138 & 12 months \\
& --- & .1415 & .2261 & .3063 & $\begin{array}{c}\text { Summer } \\
\text { Only }\end{array}$ \\
\hline 3 & .6043 & .5308 & .5298 & .5394 & $\begin{array}{c}12 \text { months } \\
\text { Summer } \\
\text { Only }\end{array}$ \\
\hline
\end{tabular}

Table 6, Boiler [C]

Seasonal Performance Factor (SPF) for Boiler [C].

\begin{tabular}{|cccccc|}
\hline $\mathrm{H}_{\mathrm{O}}$ & 0 & $\begin{array}{c}40 \\
\text { gal/day }\end{array}$ & $\begin{array}{c}80 \\
\text { gal/day }\end{array}$ & $\begin{array}{c}120 \\
\text { gal/day }\end{array}$ & Season \\
\hline 1 & .6723 & .6338 & .6447 & .6565 & 12 months \\
&.-- & .2315 & .3787 & .4906 & $\begin{array}{c}\text { Summer } \\
\text { Only }\end{array}$ \\
\hline 2 & .6242 & .5695 & .5704 & .5803 & 12 months \\
&.-- & .1538 & .2274 & .2972 & $\begin{array}{c}\text { Summer } \\
\text { Only }\end{array}$ \\
\hline 3 & .5725 & .5147 & .5111 & .5166 & $\begin{array}{c}12 \text { months } \\
\text { Summer } \\
\text { Only }\end{array}$ \\
\hline
\end{tabular}




\section{Table 7}

Normalized Annual Consumption of Number 2 Fuel Oil for Various Conditions

\begin{tabular}{|lccccc|}
\hline $\mathrm{H}_{\mathrm{O}}$ & 0 & $\begin{array}{c}40 \\
\text { gal/day }\end{array}$ & $\begin{array}{c}80 \\
\text { gal/day }\end{array}$ & $\begin{array}{c}120 \\
\text { gal/day }\end{array}$ & Boiler \\
\hline 1 & 1.000 & 1.135 & 1.233 & 1.337 & $\mathrm{~A}$ \\
1 & 1.113 & 1.316 & 1.411 & 1.533 & $\mathrm{~B}$ \\
\hline 1 & 1.200 & 1.409 & 1.518 & 1.622 & $\mathrm{C}$ \\
\hline 2 & 1.029 & 1.223 & 1.301 & 1.390 & $\mathrm{~A}$ \\
2 & 1.218 & 1.504 & 1.632 & 1.735 & $\mathrm{~B}$ \\
\hline 3 & 1.293 & 1.568 & 1.716 & 1.835 & $\mathrm{C}$ \\
\hline 3 & 1.072 & 1.327 & 1.409 & 1.491 & $\mathrm{~A}$ \\
\hline 3 & 1.409 & 1.735 & 1.916 & 2.062 & $\mathrm{C}$ \\
\hline
\end{tabular}

Table 8, Boiler [A]

Annual Electrical Usage (kwt-hr) .

\begin{tabular}{|ccccc|}
\hline$H_{0}$ & 0 & $\begin{array}{c}40 \\
\text { gal/day }\end{array}$ & $\begin{array}{c}80 \\
\text { gal/day }\end{array}$ & $\begin{array}{c}120 \\
\text { gal/day }\end{array}$ \\
\hline 1 & 895 & 942 & 969 & 1000 \\
2 & 677 & 713 & 723 & 734 \\
3 & 601 & 640 & 647 & 653 \\
\hline
\end{tabular}


Table 9, Boiler [B]

Annual Electrical Usage (kwt-hr)

\begin{tabular}{|ccccc|}
\hline $\int_{u} u$ & 0 & $\begin{array}{c}40 \\
\text { gal/day }\end{array}$ & $\begin{array}{c}80 \\
\text { gal/day }\end{array}$ & $\begin{array}{c}120 \\
\text { gal/day }\end{array}$ \\
\hline 1 & 913 & 981 & 1005 & 1037 \\
2 & 706 & 757 & 774 & 785 \\
3 & 639 & 680 & 696 & 706 \\
\hline
\end{tabular}

Table 10, Boiler [C]

Annual Electrical Usage (kwt-hr)

\begin{tabular}{|ccccc|}
\hline$H_{0}$ & 0 & $\begin{array}{c}40 \\
\text { gal/day }\end{array}$ & $\begin{array}{c}80 \\
\text { gaj.day }\end{array}$ & $\begin{array}{c}120 \\
\text { gal/day }\end{array}$ \\
\hline 1 & 915 & 980 & 1005 & 1027 \\
2 & 704 & 718 & 767 & 780 \\
3 & 637 & 672 & 688 & 699 \\
\hline
\end{tabular}


Table 11, Boiler [A]

Annual Operating Costs. N.Y. Metropolitan Area. Cost bases:

(1) Number 2 fuel oil a $\$ 0.47 / \mathrm{gal},(2)$ electrical energy a $\$ 0.045 / \mathrm{kwt}-\mathrm{hr}$. Energy usage based on Tables 1 and 8 .

\begin{tabular}{|c|c|c|c|c|c|}
\hline$\alpha_{0}^{H}$ & 0 & $\begin{array}{c}40 \\
\text { gal/day }\end{array}$ & $\begin{array}{c}80 \\
\text { gal/day }\end{array}$ & $\begin{array}{c}120 \\
\text { gal/day }\end{array}$ & \\
\hline 1 & $\begin{array}{r}\$ 467 \\
40 \\
\$ 507\end{array}$ & $\begin{array}{r}\$ 530 \\
\quad 42 \\
\$ 572\end{array}$ & $\begin{array}{r}\$ 575 \\
\quad 44 \\
\$ 619\end{array}$ & $\begin{array}{r}\$ 624 \\
\quad 45 \\
\$ 669\end{array}$ & $\begin{array}{l}\text { Oil } \\
\text { Elec. } \\
\text { Total }\end{array}$ \\
\hline 2 & $\begin{array}{r}\$ 480 \\
\quad 30 \\
\$ 510\end{array}$ & $\begin{array}{l}\$ 571 \\
\frac{32}{\$ 603}\end{array}$ & $\begin{array}{r}\$ 607 \\
\$ \frac{33}{\$ 640}\end{array}$ & $\begin{array}{r}\$ 649 \\
\quad 33 \\
\$ 682\end{array}$ & $\begin{array}{l}\text { Oil } \\
\text { Elec. } \\
\text { Total }\end{array}$ \\
\hline 3 & $\begin{array}{r}\$ 500 \\
27 \\
\$ 527\end{array}$ & $\begin{array}{r}\$ 619 \\
29 \\
\$ 648\end{array}$ & $\begin{array}{r}\$ 657 \\
29 \\
\$ 686\end{array}$ & $\begin{array}{r}\$ 696 \\
29 \\
\$ 725\end{array}$ & $\begin{array}{l}\text { Oil } \\
\text { Elec. } \\
\text { Total }\end{array}$ \\
\hline
\end{tabular}

Table 12, Boiler [B]

Annual Operating Costs. Metropolitan N.Y. Area. Cost bases:

(1) Number 2 fuel oil @ $\$ 0.47 / \mathrm{gal}$, (2) electrical energy a

$\$ 0.045 / \mathrm{kwt}-\mathrm{hr}$. Energy usage based on data of Tables 2 and 9 .

\begin{tabular}{|c|c|c|c|c|c|}
\hline$\alpha_{\alpha}^{H}$ & 0 & $\begin{array}{c}40 \\
\text { gal/day }\end{array}$ & $\begin{array}{c}80 \\
\text { gal/day }\end{array}$ & $\begin{array}{c}120 \\
\text { ga } 1 / \text { day }\end{array}$ & \\
\hline 1 & $\begin{array}{r}\$ 519 \\
41 \\
\$ 560\end{array}$ & $\begin{array}{r}\$ 614 \\
\frac{44}{\$ 658}\end{array}$ & $\begin{array}{r}\$ 658 \\
\quad 45 \\
\$ 703\end{array}$ & $\begin{array}{r}\$ 715 \\
46 \\
\$ 761\end{array}$ & $\begin{array}{l}\text { Oil } \\
\text { Elec. } \\
\text { Total }\end{array}$ \\
\hline 2 & $\begin{array}{l}\$ 568 \\
\frac{32}{\$ 600}\end{array}$ & $\begin{array}{r}\$ 702 \\
\frac{34}{\$ 736}\end{array}$ & $\begin{array}{r}\$ 761 \\
\quad 35 \\
\$ 796\end{array}$ & $\begin{array}{r}\$ 810 \\
35 \\
\$ 845\end{array}$ & $\begin{array}{l}\text { Oil } \\
\text { Elec. } \\
\text { Total }\end{array}$ \\
\hline 3 & $\begin{array}{r}\$ 623 \\
29 \\
\$ 652\end{array}$ & $\begin{array}{r}\$ 785 \\
\frac{31}{\$ 816}\end{array}$ & $\begin{array}{r}\$ 862 \\
31 \\
\$ 893\end{array}$ & $\begin{array}{r}\$ 921 \\
\$ 32 \\
\$ 953\end{array}$ & $\begin{array}{l}\text { Oil } \\
\text { Elec. } \\
\text { Total }\end{array}$ \\
\hline
\end{tabular}


Table 13, Boiler [C]

Annual Operating Costs. N.Y. Metropolitan Area. Cost bases: (1) Number 2 fuel oil @ $\$ 0.47 / \mathrm{gal}$, (2) electrical energy a \$0.045/kwt-hr. Energy usage based on data of Tables 3 and 10 .

\begin{tabular}{|c|c|c|c|c|c|}
\hline$\alpha$ & 0 & $\begin{array}{c}40 \\
\text { gal/day }\end{array}$ & $\begin{array}{c}80 \\
\text { gal/day }\end{array}$ & $\begin{array}{c}120 \\
\mathrm{gal} / \mathrm{day}\end{array}$ & \\
\hline 1 & $\begin{array}{r}\$ 560 \\
\frac{41}{\$ 601}\end{array}$ & $\begin{array}{r}\$ 657 \\
\frac{44}{\$ 701}\end{array}$ & $\begin{array}{r}\$ 709 \\
\quad 45 \\
\$ 754\end{array}$ & $\begin{array}{r}\$ 757 \\
46 \\
\$ 803\end{array}$ & $\begin{array}{l}\text { Oil } \\
\text { Elec. } \\
\text { Total }\end{array}$ \\
\hline 2 & $\begin{array}{l}\$ 603 \\
\frac{32}{\$ 635}\end{array}$ & $\begin{array}{r}\$ 732 \\
34 \\
\$ 766\end{array}$ & $\begin{array}{l}\$ 801 \\
\frac{35}{\$ 836}\end{array}$ & $\begin{array}{r}\$ 856 \\
\frac{35}{\$ 891}\end{array}$ & $\begin{array}{l}\text { Oil } \\
\text { Elec. } \\
\text { Total }\end{array}$ \\
\hline 3 & $\begin{array}{r}\$ 658 \\
29 \\
\$ 687\end{array}$ & $\begin{array}{r}\$ 809 \\
30 \\
\$ 839\end{array}$ & $\begin{array}{r}\$ 894 \\
31 \\
\$ 925\end{array}$ & $\begin{array}{l}\$ 962 \\
\frac{31}{\$ 993}\end{array}$ & $\begin{array}{l}\text { nil } \\
\text { Elec. } \\
\text { Total }\end{array}$ \\
\hline
\end{tabular}

Table 14

Measured COP (Overall) for a High Quality Air=to-Air Heat Pump Sized to Heat a 50,000 Btuh Design Load. (NBS data, reference 5). Return air of $66^{\circ} \mathrm{F}$; $1680 \mathrm{CFM}$ fan. (Heating only)

\begin{tabular}{|cc|}
\hline Measured (COP) & Outdoor Temp. \\
\hline 1.05 & $2{ }^{\circ} \mathrm{F}$ \\
1.22 & $12^{\circ} \mathrm{F}$ \\
1.42 & $22^{\circ} \mathrm{F}$ \\
1.60 & $32^{\circ} \mathrm{F}$ \\
2.12 & $42^{\circ} \mathrm{F}$ \\
2.17 & $52^{\circ} \mathrm{F}$ \\
2.18 & $62^{\circ} \mathrm{F}$ \\
\hline
\end{tabular}


Table 15

Annual Performance of an Air-to-Air Heat Pump loperating COP of Table 14) serving a 50,000 Btuh design heat load in a N.Y. Metropolitan winter ( 10 year hourly weather data). Heating plus domestic hot water only)

\begin{tabular}{|cccccc|}
\hline Ho & 0 & $\begin{array}{c}40 \\
\text { gal/day }\end{array}$ & $\begin{array}{c}80 \\
\text { gal/day }\end{array}$ & $\begin{array}{c}120 \\
\text { gal/day }\end{array}$ & \\
\hline $\begin{array}{c}\text { Annual } \\
\text { kwt-hrs } \\
\text { used }\end{array}$ & 20,400 & 24,005 & 27,609 & 31,214 & \\
\hline $\begin{array}{c}\text { Annual } \\
\text { Costs of } \\
\text { Electrical } \\
\text { Energy } \\
\text { (Heat Plus }\end{array}$ & $\$ 812$ & $\$ 120$ & $\$ 828$ & $\$ 936$ & a $\$ 0.03 / \mathrm{kwt}-\mathrm{hr}$ \\
Domestic h.w) $\$ 1020$ & $\$ 1200$ & $\$ 1380$ & $\$ 1561$ & e $\$ 0.05 / \mathrm{kwt}-\mathrm{hr}$ \\
\hline $\begin{array}{c}\text { Overall } \\
\text { (Seasonal) } \\
\text { cop }\end{array}$ & 1.72 & 1.61 & 1.53 & 1.47 & \\
\hline
\end{tabular}




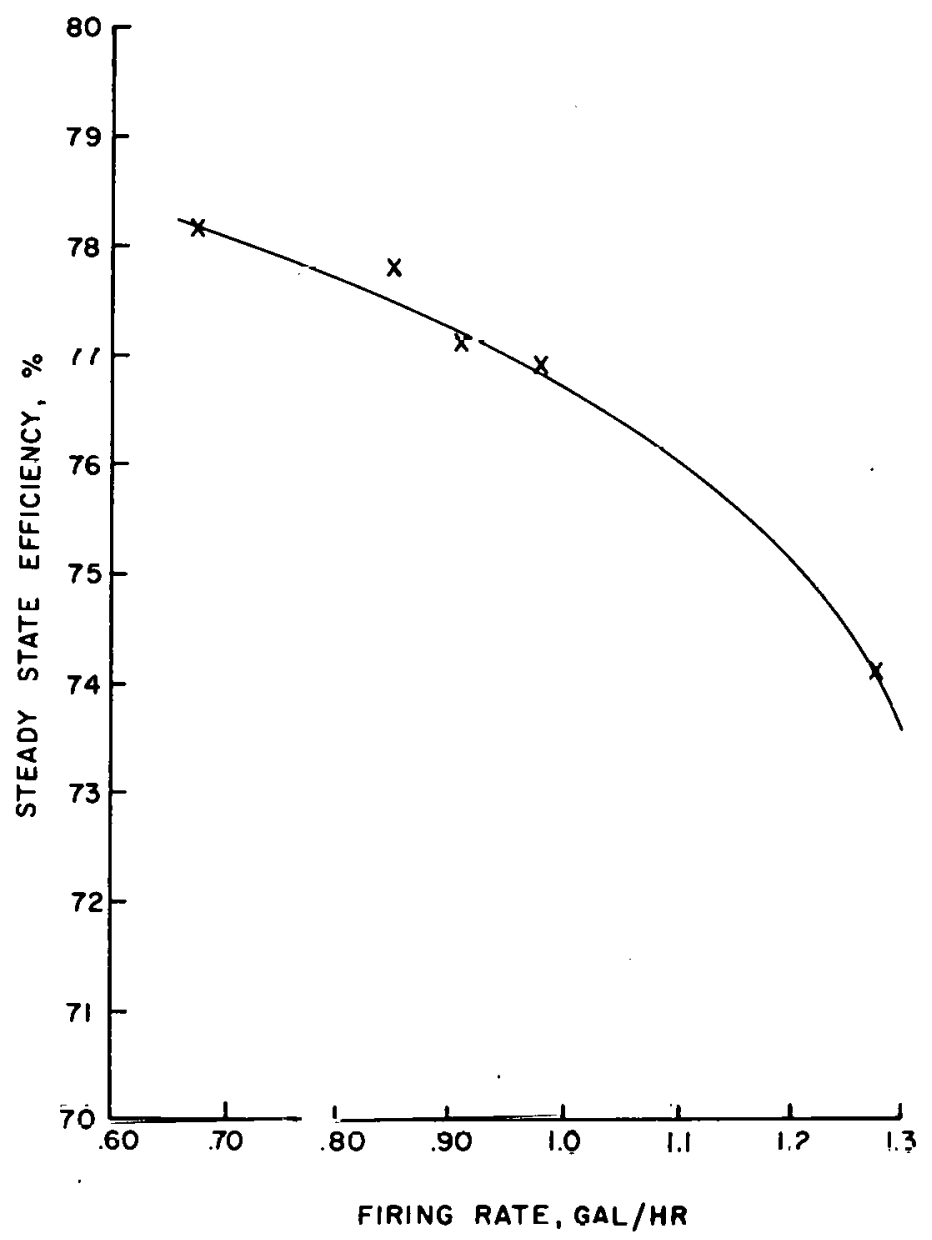

Figure 1. Steady state efficiency vs, firing rate for a steel fire-tube boiler. 


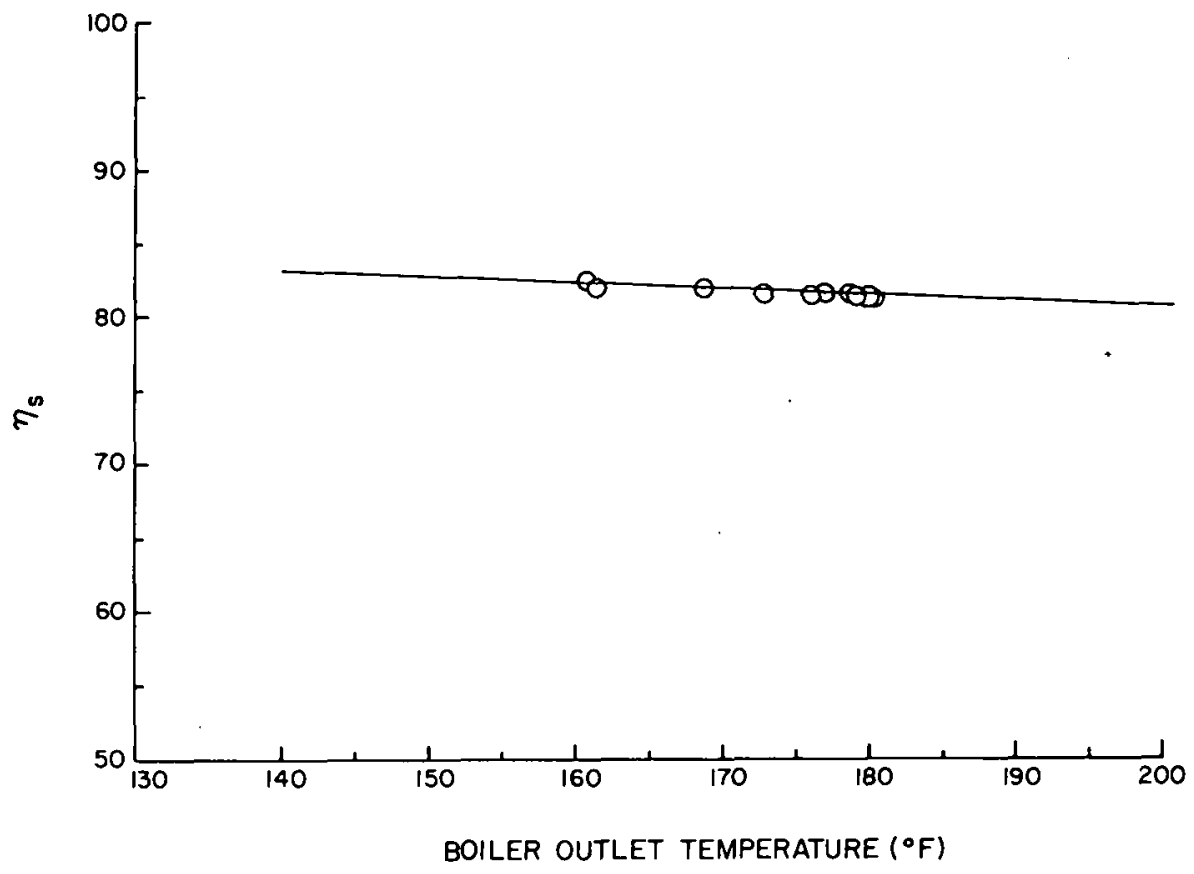

Figure 2a. Steady state efficiency (\%) vs. boiler outlet temperature $\left({ }^{\circ} \mathrm{F}\right)$ for boiler [A].

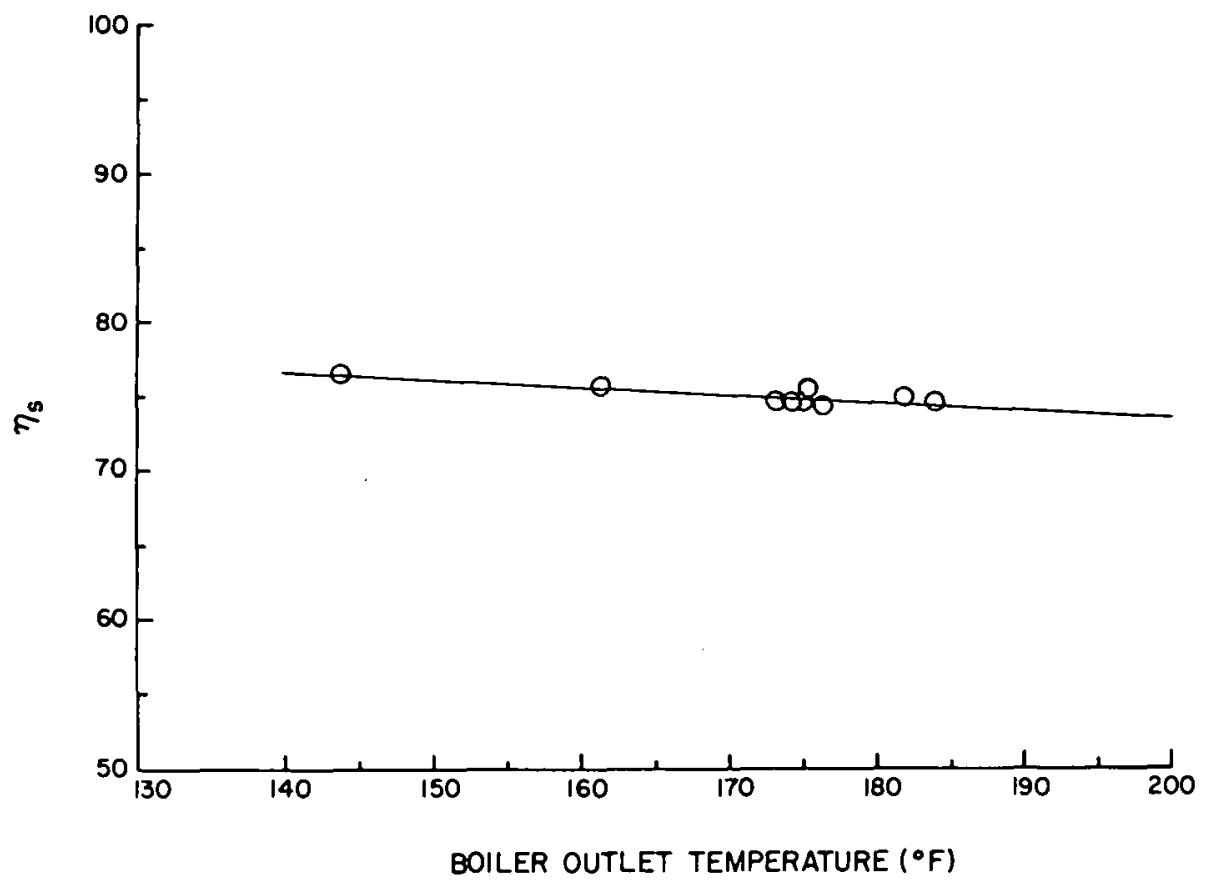

Figure 2b. Steady state efficiency (\%) vs. boiler outlet temperature ( ${ }^{n} F$ ) for boiler [B]. 


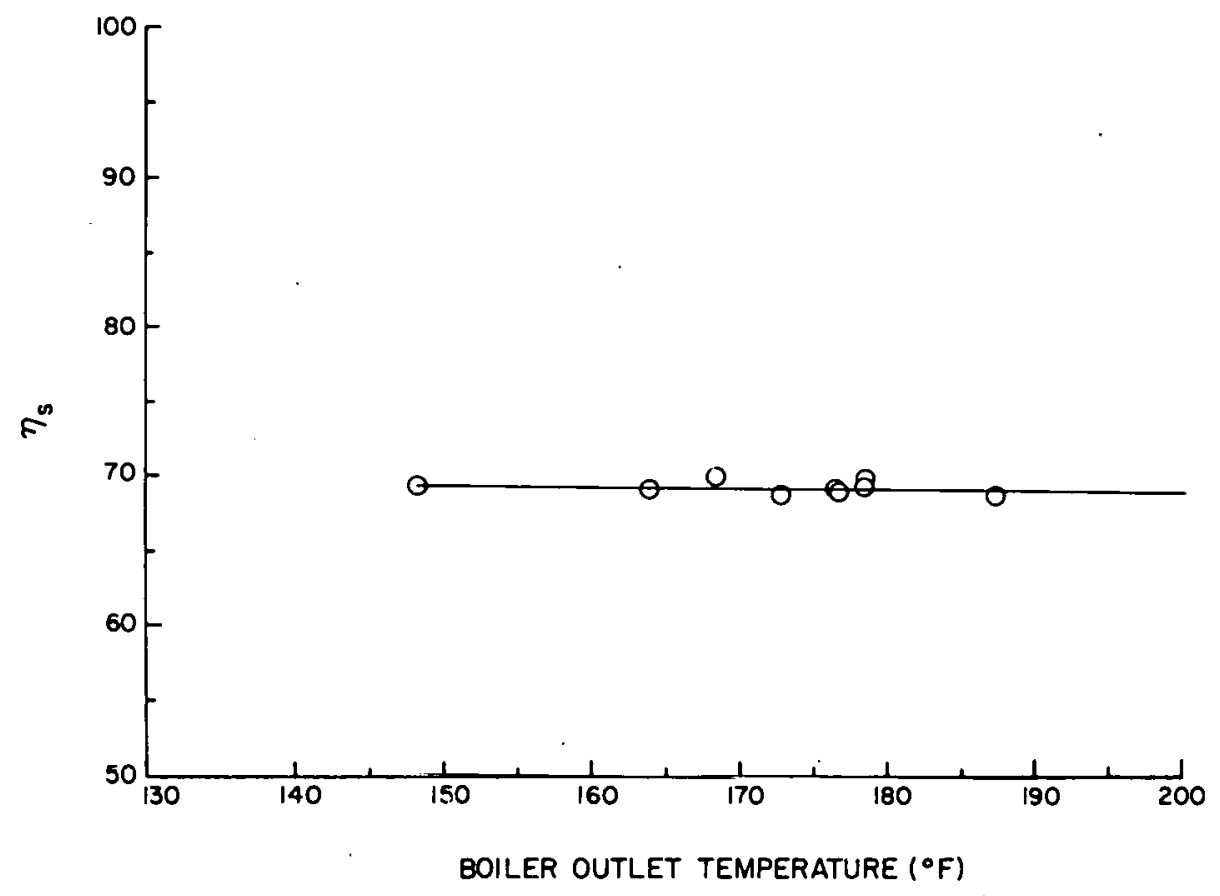

Figure 2c. 'Steady state efficiency (\%) vs. boiler outlet temperature $\left({ }^{\circ} \mathrm{F}\right)$ for boiler [C].

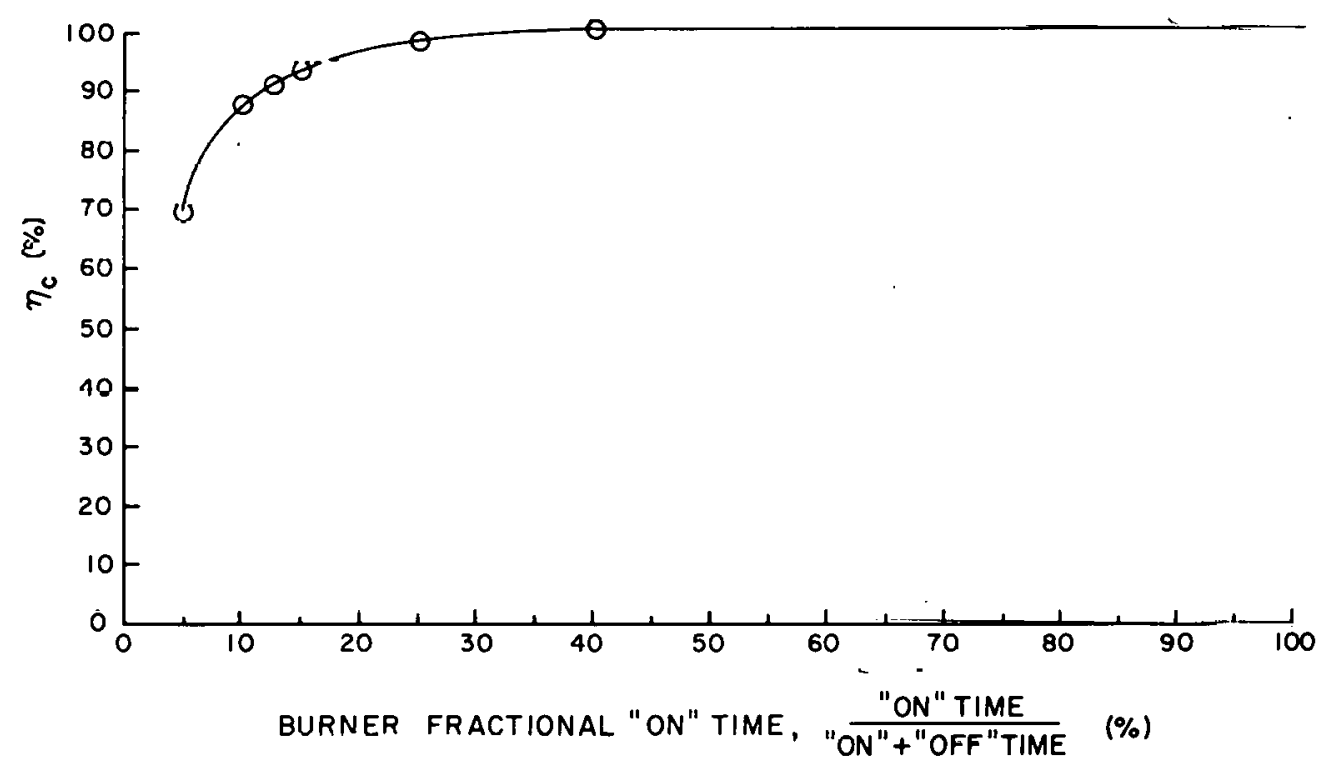

Figure 3a. Cycle efficiency $\left(n_{c}\right)$ vs. burner fractional "nn" time (\%) for boiler [A]. 


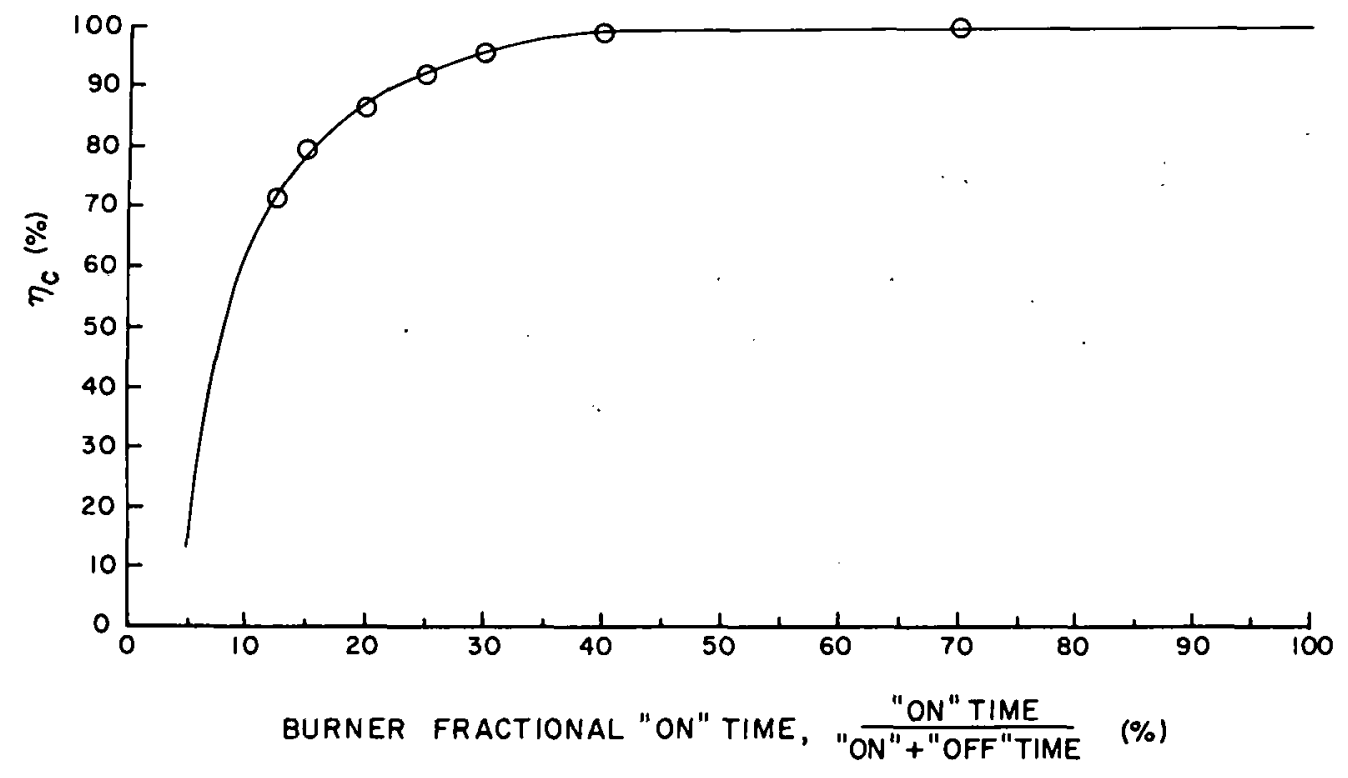

Figure 3b. Cycle efficiency $\left(n_{c}\right)$ vs. burner fractional "on" time (\%) for boiler [B].

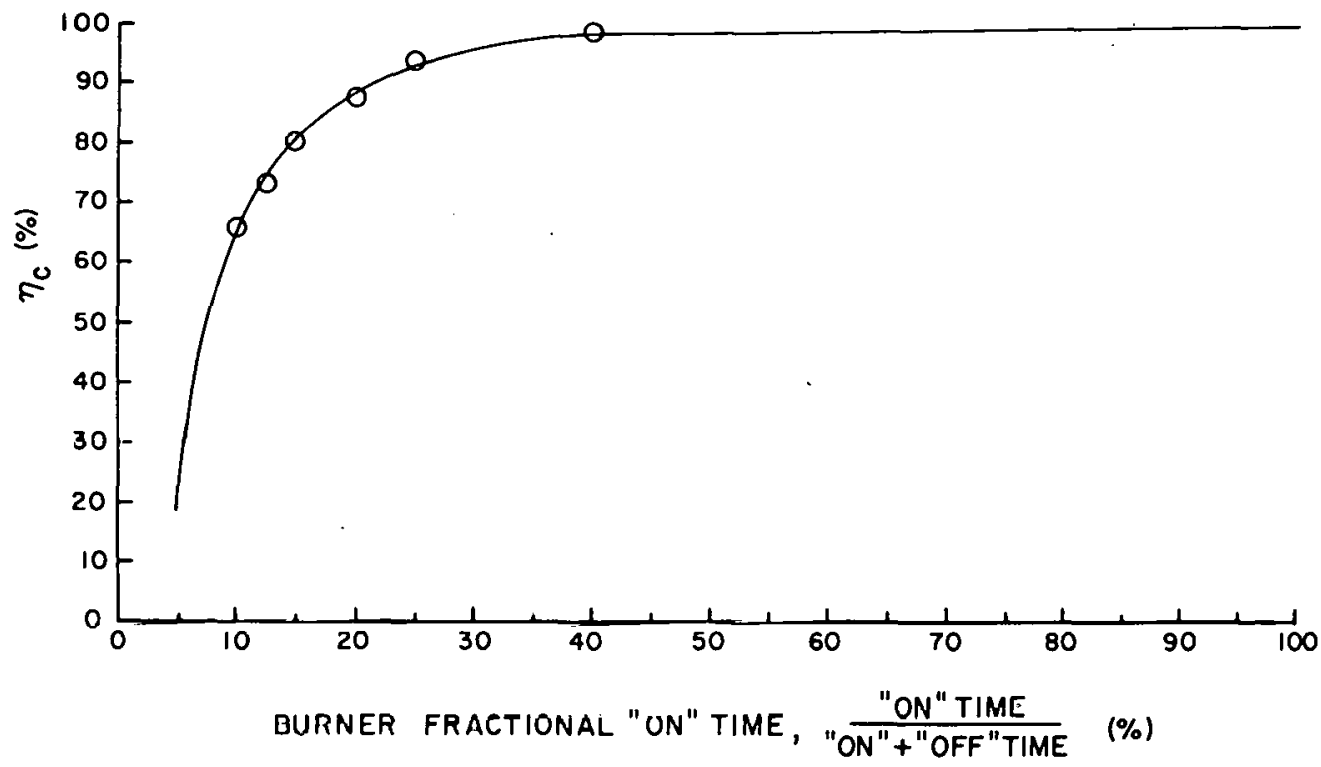

Figure 3c. Cycle efficiency $\left(n_{c}\right)$ vs. burner fractional "on" time (\%) for boiler [C]. 


\section{References}

1. Berlad, A. L., and Batey, J. Performance Evaluation and Economic Impact of Oil-Fired Residential Heating. J. Urban Analysis 1 , 95 (1972).

2. Berlad, A. L., Salzano, F. J., and Batey J. On Enthalpy Management in Small Buildings. ENERGY - The International Journal, 1, 429 (1976). BNL 20572 and BNL 21577.

3. Berlad, A. L., Lin, H. C., Salzano, F. J., and Batey, J. Comfort Range Thermal storage. ENERGY - The International Journal (In Press). BNL 21591. July 1976.

4. Bonne, U., Johnson, A. E., Glatzel, J., and Torbor, R. Analysis of New England Oil Burner Data. Effect of Reducing Excess Firing Rate on Seasonal Efficiency. Final Report by Honeywell Corporate Research Center on NBS Contract 514736, August 1975.

5. Kelley, G. E., and Bean, J. Dynamic Performance of a Residential Air-to-Air Heat Pump. National Bureau of Standards Report BSS-93, 1976.

6. E CUBE Weather Data, American Gas Association, Arlington, Virginia, 1975 . 
Part A Evaluation of Seasonal Performance of an Oil or Gas-Fired Boiler/Furnace

For the heating season:

Eq. (2a) can be rewritten as

$$
\dot{m}_{f, i} \eta_{c, i} \eta_{s} \Delta_{c}=\mathscr{L}_{d}\left[\frac{T^{*}-T_{C, i}}{T^{*}-T_{d}}\right]+H_{o} \text {, where } T_{c, i}<T^{*}(A-1)
$$

Eq. (2b) yields

$$
\dot{\mathrm{m}}_{\mathrm{f}, \mathrm{d}} \eta_{\mathrm{s}} \Delta_{\mathrm{c}}=\left(\mathscr{L}_{\mathrm{d}}+\mathrm{H}_{\mathrm{o}}\right) \alpha
$$

$(A-1 / A-2)$ yields

$$
n_{c, i}\left(\frac{\dot{m}_{f, i}}{\dot{m}_{f, d}}\right)=\left\{\mathscr{L} \cdot\left[\frac{T_{d}^{*}-T_{c, i}}{T^{*}-T_{d}}\right]+H_{o}\right\} /\left(\dot{m}_{f, d} \Delta_{c} n_{s}\right)
$$

or

$$
\Lambda_{i}=\ell_{i}
$$

Laboratory tests will provide $n_{c, i}$ vs. $\frac{\stackrel{n}{f, i}_{\dot{m}_{f, d}}}{\dot{m}_{f}}$ Thus $Q_{H S}$ is known once all the parameters are given. We then ronstruct a relation between $\Lambda_{i}$ and $\frac{\dot{m}_{f, i}}{\dot{m}_{f, d}}$. Therefore, once $Q_{i}$ is known, $\Lambda_{i}$ is obtained automatically. By interpolation, we find the corresponding $\frac{m_{f, i}}{\dot{m}_{f, d}}$; this in turn gives $\dot{\mathrm{m}}_{\mathrm{f}, i}$ and

$$
\mathrm{M}_{1}=\sum \dot{m}_{\mathrm{f}, \mathrm{i}} \mathrm{n}_{i}
$$


For the nonheating season:

$$
\begin{aligned}
\dot{m}_{f}^{*}= & \frac{H_{0} \dot{m}_{f, d}}{n_{c}^{*}\left(\mathscr{L}_{\mathrm{d}}+H_{o}\right) \alpha}=\frac{H_{o}}{n_{c}^{*} n_{s} \Delta_{c}} \\
& \cdot n_{c}^{*} \frac{\dot{m}_{f}^{*}}{\dot{m}_{f, d}}=\frac{H_{0}}{\left(H_{0}+\mathscr{L}_{d}\right) \alpha}
\end{aligned}
$$

Again, by interpolation, we get $\frac{\dot{\mathrm{m}}_{\mathrm{f}}^{*}}{\dot{\mathrm{m}}_{\mathrm{f}, \mathrm{d}}}$ and thus obtain $\dot{\mathrm{m}}_{\mathrm{f}}^{*}$.

$$
\mathrm{M}_{2}=\dot{\mathrm{m}}_{\hat{\mathrm{f}}}^{\star} \mathrm{n}^{*}
$$

For a perfect unit (efficiency of unity)

$$
\begin{aligned}
& \dot{\mathrm{m}}_{\mathrm{f}, i} \mathrm{p}=\boldsymbol{\alpha}\left\{\left[\frac{\mathrm{T}^{*}-\mathrm{T}_{\mathrm{c}, \mathrm{i}}}{\mathrm{T}^{*}-\mathrm{T}_{\mathrm{d}}}\right]+\mathrm{H}_{\mathrm{O}}\right\} / \mathrm{H}_{\mathrm{C}} \\
& M_{1}^{p}=\sum \dot{m}_{f, i} p n_{i} \\
& \dot{m}_{\mathrm{f}}^{*} \mathrm{P}=\frac{\mathrm{H}_{\mathrm{O}}}{\Delta_{\mathrm{C}}} \\
& M_{2}^{P}=\frac{110}{\Delta_{c}} n^{*} \\
& \text { SPF }=\frac{M_{1}^{p}+M_{2}^{p}}{M_{1}+M_{2}}
\end{aligned}
$$

A printout of the Program SPE is attached as Part D.

Part B Evaluation of Seasonal Performance of an Air-to-Air Heat Pump

SPF of a heat pump can be defined as

$$
\begin{aligned}
& \mathrm{SPF}=\mathrm{TPH}+\mathrm{TRH}+\mathrm{TDH} \\
& \sum \frac{\left(\mathrm{TPH}_{i}\right)\left(\mathrm{n}_{i}\right)}{\left(\mathrm{COP}_{\mathrm{H}}\right)_{i}}+\frac{(\mathrm{TRH}+\mathrm{TDH})}{\mathrm{COP}_{\mathrm{R}}}
\end{aligned}
$$


where

$\mathrm{TPH}_{i}=$ thermal energy delivered by heat pump at the $i^{\text {th }}$ temperature,

$\mathrm{TPH}=\sum \mathrm{TPH}_{i}\left(\mathrm{n}_{i}\right)$

$n_{i}=$ Number of hours associated with the $i^{\text {th }}$ temperature;

TPH = Total thermal energy delivered by heat pump

$\mathrm{TRH}=$ Total thermal energy delivered by resistance heater for heating;

$\mathrm{TDH}=$ Total thermal energy delivered by resistance heater for domestic hot water;

$(\mathrm{COP})_{h, i}=$ Coeff. of Performance of heat pump at $i^{\text {th }}$ temperature.

$\sum \frac{\mathrm{THP}_{i}\left(\mathrm{n}_{i}\right)}{(\mathrm{COP}) \mathrm{H}_{i}}=$ Total electrical energy delivered to heat pump ${ }^{C O P}{ }_{R}=$ Coeff. of Performance for resistance heaters for heater, $(=1)$.

$\frac{\mathrm{TRH}}{\mathrm{COP}_{\mathrm{R}}}=$ Total electrical energy delivered to the resistance heaters for heating;

$\underline{\mathrm{TDH}}=$ Total electrical energy delivered to the resistance $\overline{\mathrm{COP}_{R}}$ heaters for hot water.

To compute SPF, we have to first find $T_{B}$, the balance point of heat pump operation; for $\mathrm{T}_{i}<\mathrm{T}_{\mathrm{B}^{\prime}}$, supplementary (resistance) heat is required.

Ref. 5 gives performance information of a heat pump designed to meet a 50,000 Btuh heating load. COP, heating requirement and supplementary heat (if any) at each temperature are given. 
Starting from the lowest temperature encountered, we can find the heat requirement, COP, and the supplementary heat requirement at each temperature.

Inasmuch as

$$
\begin{aligned}
& \mathrm{TRH}=\sum \mathrm{TRH}_{i}\left(\mathrm{n}_{i}\right) \\
& \mathrm{TDH}=Q(\mathrm{DT}) \mathrm{n}_{i}
\end{aligned}
$$

where

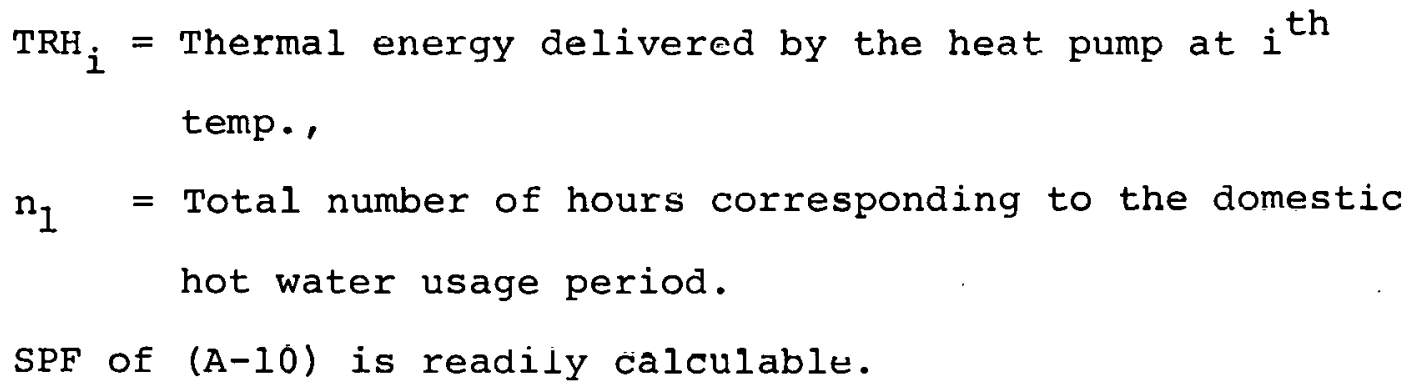

Part C Ten-Year Hourly Average Weather Data ${ }^{6}$ for Three Representative Climates. Eight-Month Heating Season and TwelveMonth Heating Season

Tabulated below are the number of hour per heating saason for metropolitan New York City, Minneapolis and Washington, D.C. Column (A) gives the number of hours for an eight-month season. Column (B) gives the number of hours for a twelve-month season. Temp. $\left({ }^{\circ} \mathrm{F}\right) \quad$ New York Minneapolis Washington, D.C.
(A)
(B)
(A)
(B)
$(A) \cdot(B)$

$-20$

00

$0 \quad 0$

$0 \quad 0$

$-19$

$0 \quad 0$

$0 \quad 0$

$0 \quad 0$

$-18$

$0 \quad 0$

22

$0 \quad 0$

-continued- 
Temp. $\left({ }^{\circ} \mathrm{F}\right) \quad$ New York

(A) (B)

$-17$

$-16$

$-15$

$-14$

$-13$

$-12$

$-11$

$-10$

$-9$

$-8$

$-7$

$-6$

$-5$

$-4$

$-3$

$-2$

$-1$

0

1

2

3

4

5

6

7
$0 \quad 0$

$0 \quad 0$

00

00

$0 \quad 0$

$0 \quad 0$

$0 \quad 0$

$0 \quad 0$

$0 \quad 0$

$0 \quad 0$

$0 \quad 0$

$0 \quad 0$

$0 \quad 0$

$0 \quad 0$

$0 \quad 0$

$0 \quad 0$

$0 \quad 0$

$0 \quad 0$

$0 \quad 0$

$0 \quad 0$

33

22

$0 \quad 0$

22

22
Minneapolis

(A) (B)

33

66

$10 \quad 10$

55

$8 \quad 8$

$11 \quad 11$

$16 \quad 16$

$16 \quad 16$

$8 \quad 8$

$19 \quad 19$

$19 \quad 19$

$16 \quad 16$

$25 \quad 25$

$29 \quad 29$

$30 \quad 30$

$\begin{array}{ll}37 & 37\end{array}$

$41 \quad 41$

$67 \quad 67$

$54 \quad 54$

$56 \quad 56$

$80 \quad 80$

$51 \quad 51$

$63 \quad 63$

$60 \quad 60$

$64 \quad 64$
Washington, D.C.

$$
\text { (A) (B) }
$$

$0 \quad 0$

$0 \quad 0$

00

$0 \quad 0$

$0 \quad 0$

00

$0 \quad 0$

00

00

00

00

00

$0 \quad 0$

00

$0 \quad 0$

$0 \quad 0$

$0 \quad 0$

00

$0 \quad 0$

00

00

00

$0 \quad 0$

$0 \quad 0$

$0 \quad 0$ 
Temp. $\left({ }^{\circ} F\right)$

New York

Minneapolis

Washington, D.C.

(A) (B)

8.

9

10

11

1.2.

13

14

15

16

17

18

19

20

21

22

23

24

25

26

27

28

29

30

31
22

$6 \quad 6$

44

$5 \quad 5$

$6 \quad 6$

99

$12 \quad 12$

$14 \quad 14$

$16 \quad 16$

$23 \quad 23$

$42 \quad 42$

$57 \quad 57$

$43 \quad 43$

$53 \quad 53$

$47 \quad 47$

$49 \quad 49$

$63 \quad 63$

$69 \quad 69$

$57 \quad 57$

$45 \quad 45$

$71 \quad 71$

$120 \quad 120$

$97 \quad 97$
$32 \quad 32$
(A)

(B)

$60 \quad 60$

$78 \quad 78$

$67 \quad 67$

$65 \quad 65$

$61 \quad 61$

$80 \quad 80$

$64 \quad 64$

$84 \quad 84$

$62 \quad 62$

$67 \quad 67$

$75 \quad 75$

$70 \cdot 70$

$76 \quad 76$

$68 \quad 68$

$66 \quad 66$

$95 \quad 95$

$110 \quad 110$

$119 \quad 119$

$82 \quad 82$

$123 \quad 123$

$110 \quad 110$

$101 \quad 101$

$123 \quad 123$

$88 \quad 88$
(A) (B)

$0 \quad 0$

$0 \quad 0$

$0 \quad 0$

$7 \quad 7$

$5 \quad 5$

33

$5 \quad 5$

$14 \quad 14$

99

$12 \quad 12$

$17 \quad 1 \%$

$33 \quad 33$

$46 \quad 46$

$55 \quad 55$

$48 \quad 48$

$70 \%$

$68 \quad 68$

$65 \quad 65$

$81 \quad 81$

$95 \quad 95$

$1.08 \quad 108$

$64 \quad 64$

$103 \quad 103$

125. 125 
Temp. $\left({ }^{\circ} \mathrm{F}\right)$

32

33

34

35

36

37

38

39

40

41

42

43

44

45

46

47

48

49

50

51

52

53

54

55
New - York

(A) (B)

$131 \quad 131$

$124 \quad 124$

$156 \quad 156$

$173 \quad 173$

$171 \quad 171$

$192 \quad 192$

$187 \quad 187$

$194 \quad 194$

$171 \quad 171$

$180 \quad 180$

$160 \quad 161$

$160 \quad 162$

$159 \quad 161$

$148 \quad 149$

$179 \quad 180$

$128 \quad 131$

$126 \quad 129$

$117 \quad 119$

$101 \quad 104$

$98 \quad 102$

$90 \quad 101$

$118 \quad 125$

$124 \quad 138$

$111 \quad 126$
Minneapolis

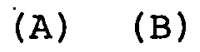

$130 \quad 130$

109109

$99 \quad 99$

101101

$106 \quad 106$

$89 \quad 89$

$100 \quad 100$

$90 \quad 94$

$92 \quad 97$

$109 \quad 112$

$107 \quad 117$

$96 \quad 103$

$96 \quad 107$

$107 \quad 117$

$88 \quad 100$

$102 \quad 120$

$101 \quad 124$

$110 \quad 146$

$98 \quad 142$

$80 \quad 120$

$86 \quad 144$

$76 \quad 114$

$63 \quad 104$

$\begin{array}{ll}75 & 128\end{array}$
Washington, D.C.

(A) (B)

$156 \quad 156$

$151 \quad 151$

$122 \quad 122$

$124 \quad 124$

$143 \quad 143$

$130 \quad 130$

$162 \quad 162$

$132 \quad 132$

$136 \quad 136$

$120 \quad 120$

$109 \quad 109$

$144 \quad 144$

$145 \quad 145$

$101 \quad 101$

$94 \quad 94$

$103 \quad 103$

$104 \quad 104$

$96 \quad 96$

$123 \quad 123$

$121 \quad 121$

$120 \quad 123$

$118 \quad 118$

$101 \quad 103$

$122 \quad 125$ 
Temp. $\left({ }^{O_{F}}\right)$

56

57

58

59

60

61

62

63

64

65

66

67

68

69
New York

(A)

(B)

114.136

$113 \quad 142$

$124 \quad 158$

$91 \quad 134$

$83 \quad 123$

$80 \quad 136$

$47 \quad 135$

$\begin{array}{ll}62 & 137\end{array}$

$93 \quad 172$

$62 \quad 162$

$54 \quad 172$

59. $\quad 170$

$65 \quad 190$

$51 \quad 208$
Minneapolis

(A) (B)

$81 \quad 128$

$72 \quad 130$

$55 \quad 144$

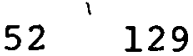

$54 \quad 146$

$30 \quad 114$

$43 \quad 139$

$32 \quad 156$

$43 \quad 148$

$38 \quad 157$

$28 \quad 135$

$22 \quad 130$

$29 \quad 153$

$16 \quad 142$
Washington, D.C.

(A) (B)

$110 \quad 114$

$99 \quad 108$

$99 \quad 110$

$117 \quad 132$

85100

$106 \quad 124$

$119 \quad 149$

$119 \quad 153$

$94 \quad 155$

$110 \quad 161$

$79 \quad 139$

$67 \quad 152$

$64 \quad 144$

$53 \quad 168$ 
Part D Program Printout

A typical calculation and printout is appended. The illustrated calculation is for Boiler $[A]$, overfired at $\alpha=2$, operating under typical metropolitan New York weather conditions, providing 40 gallons of domestic hot water per day. An 8-month heating season and a 12-month domestic hot water usage is considered. 
BNL.

SEASONAL PERFORMANCE

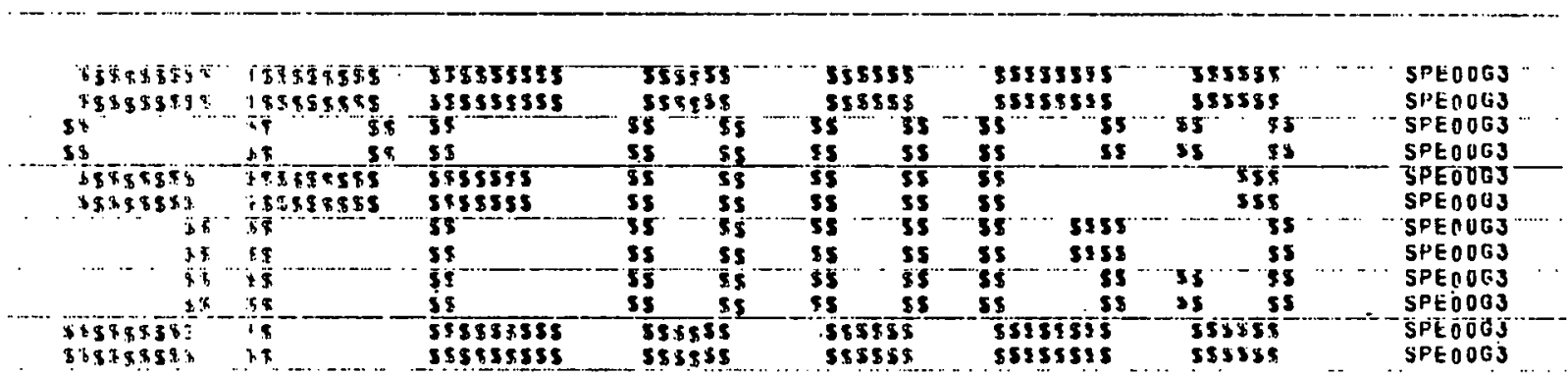

METROPOLITAN NEK YORK CALCULATION

BOILER ... A.

3.MDNTH_HEATIING SEASON

$\alpha=2$

$\dot{Q}=40$ GALMAY FOR 12 MONTHS

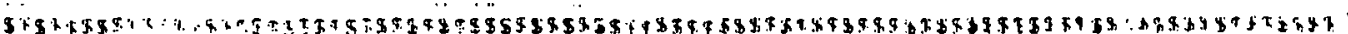

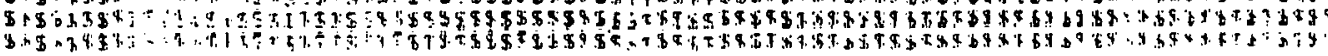

bishokgr. 


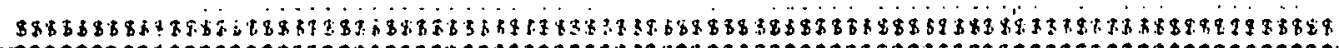

作

PROSPAM EPF

$74 / 74$ ONT $=1$ TRACF.

$\operatorname{rin} 4.5+414$

$03 / 23 / 77 \quad 14.55 .20$

PAGE

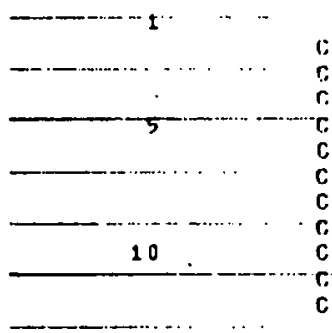

PQDT,PAIA SPL II NRUT. OINTFUT, TAFES = INPUT, TAPEG D DUTRUTI

THF PUPPOSE OF THIS PROGRAM IS TO EVALUATF SEAJONAL PFPFCRMANCE

1

FOR AN OIL OU G,AS-FIFEO POILE.P/FURNACE HITH KNOHN GRCLF EFFICIENTYY

AT ANY LOCATIOA HITH GIVEN MFATHER INF CRMATIOH.

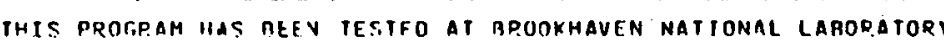

COMFUTING CEHTER.

PRAL M1:M2,MLP,MZP

PE AL NT ONTC.

OIMENSION UNAMF 1101 ,L OHETH(1O)

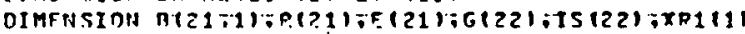

DIMFHSION NT I 901 , NTC (3)I

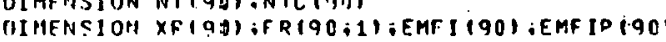

PRAOI5.10) IUNAME(I), I $=1.10)$

20 ,

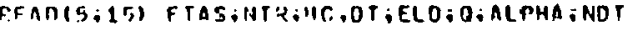

BEAO $(5,101$ HLOHETHIII,I $=1.10)$

Finanison mone

or $n \pi(5,3 n)(21,-1), 1=1,21)$

irno (b.)

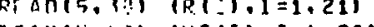

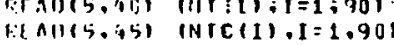

FFAnISisti Es

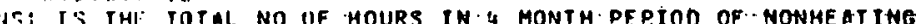

30

SENSOH

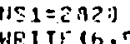

WhITE (6is)

HEI If $\{h, ?]$

WFITF(a; $A$ I

WP ITF $(6.9)$

WPI I 15,18$\}$

WP I TI $(5,1:$ )

WTI If $(5,1,1 \%$

WEI TF $(5,13)$

NHE ITE $(6,15)$

WHITF.1h.11)

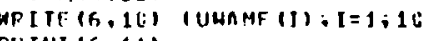

RUINI $(5,11)$

(C)

WRITF if : 1 the

HeITE (thi 15,1 TAS

MUTIF (h, O4) HC

White(tio:a) Tht

WF ITE $(0 ; 14)$ ILD

WE:IIE $(5,21)$. 1$)$

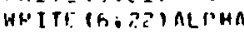

HF. I TI: $(2,53)$ HIOT

WEITI 15.25)

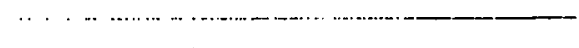




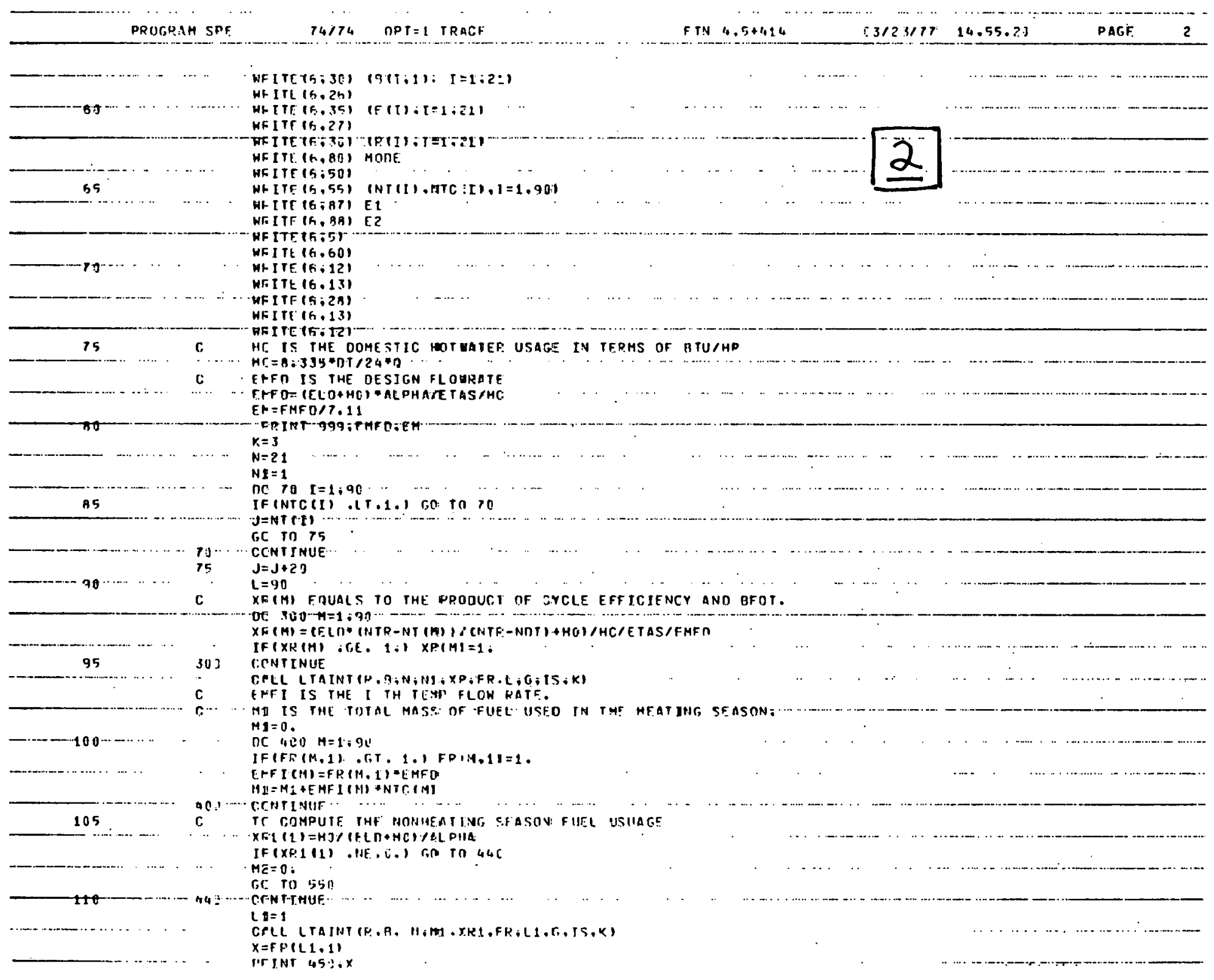




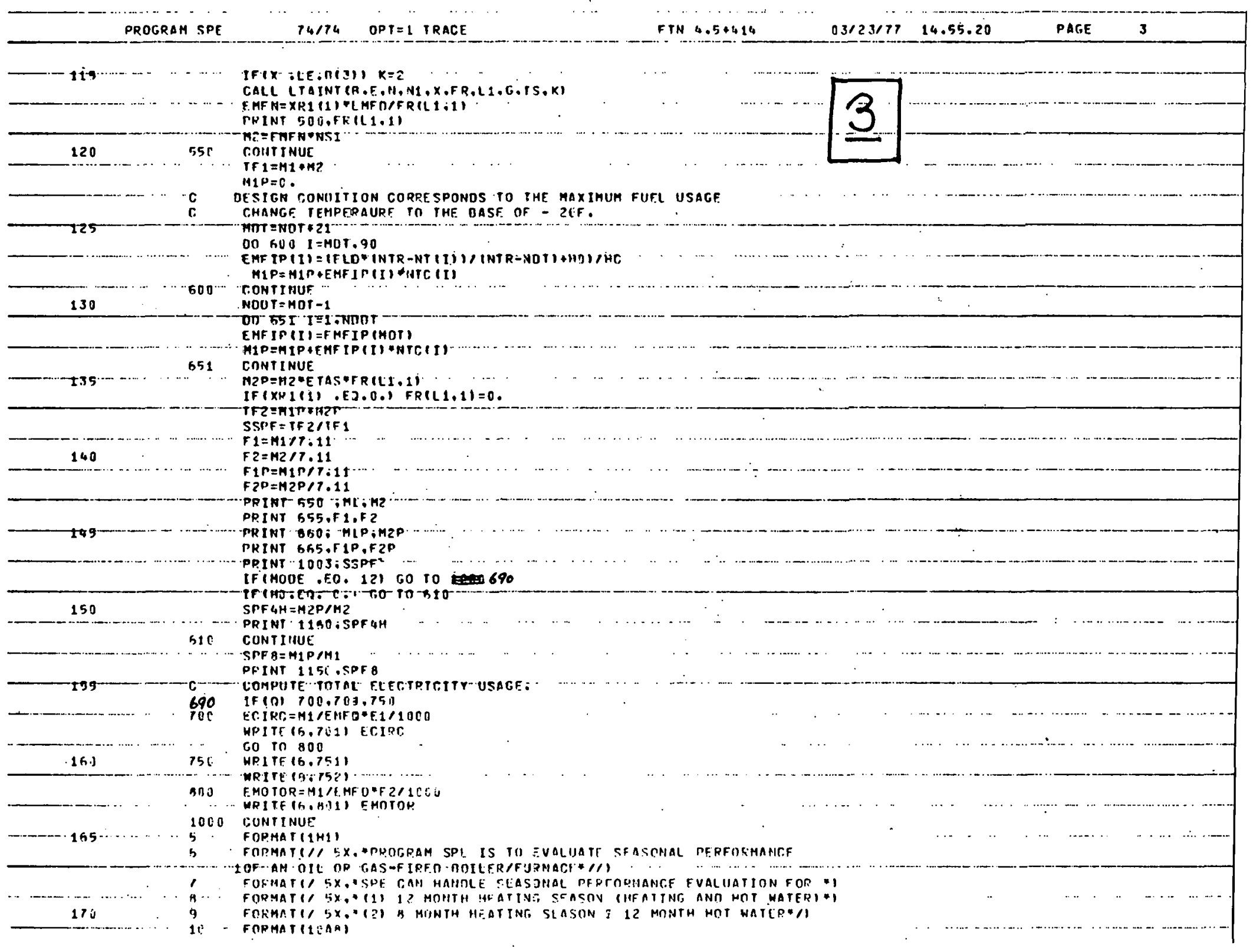


PRDGRAM SPE

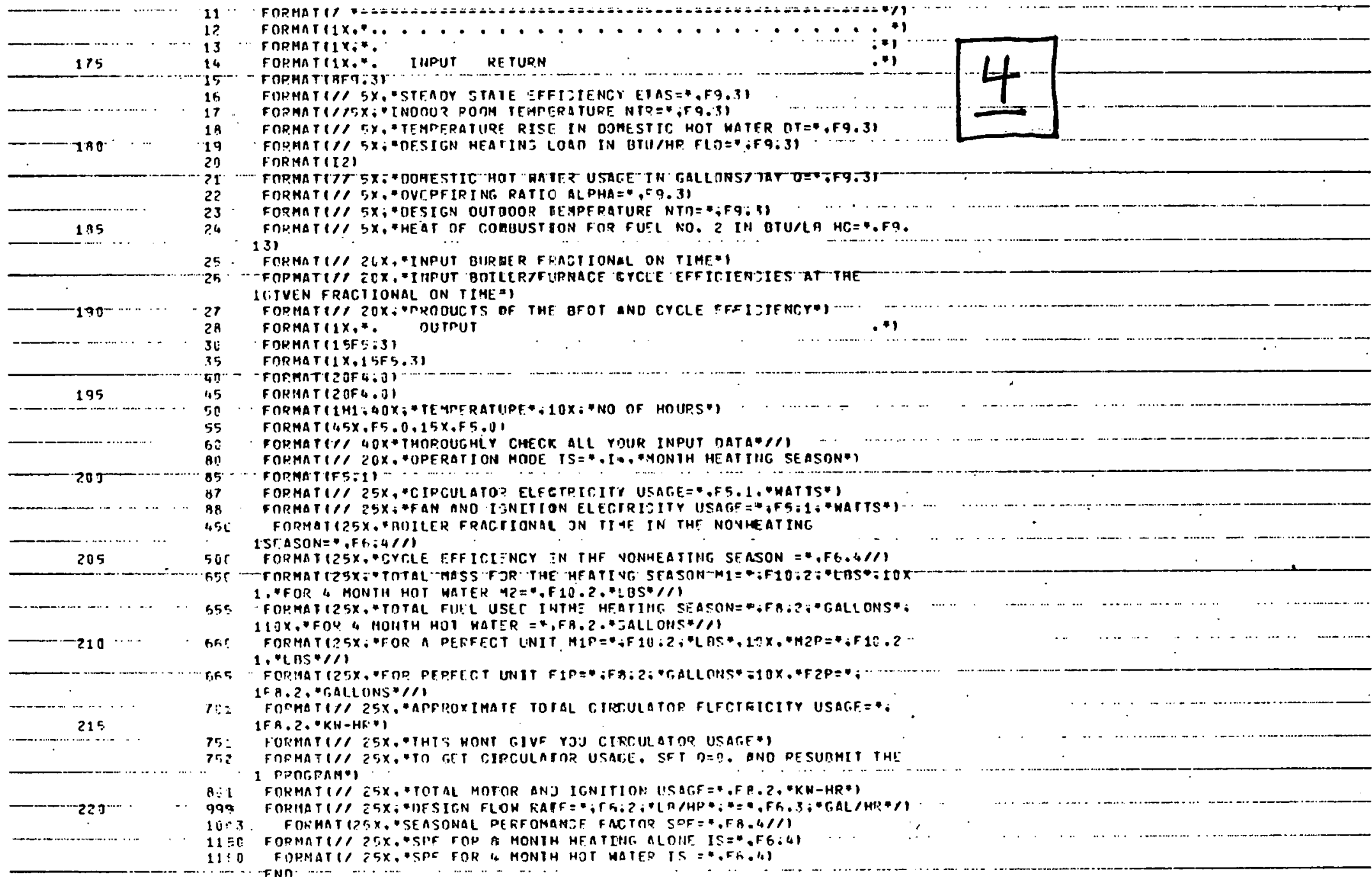




\section{- - - - stMBOLLTE REFE RENGE MAP $(P=1)$}

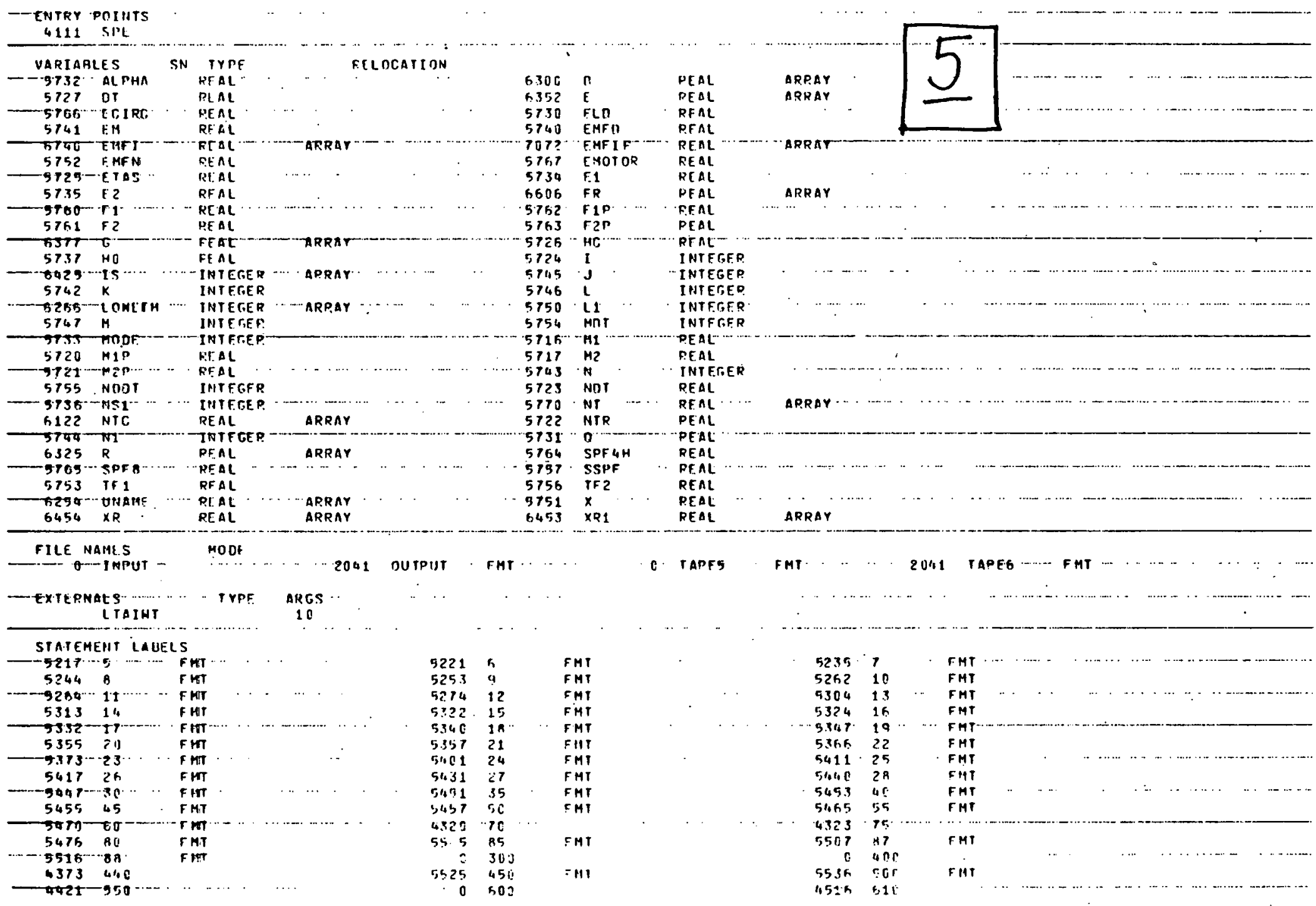


TPOGRAM SAE

$74 / 74 \quad J P T=1$ TPAGE

FTN $4.5+4.14$

$[3 / 2317] \quad 14.55 .27]$

PACFF

6

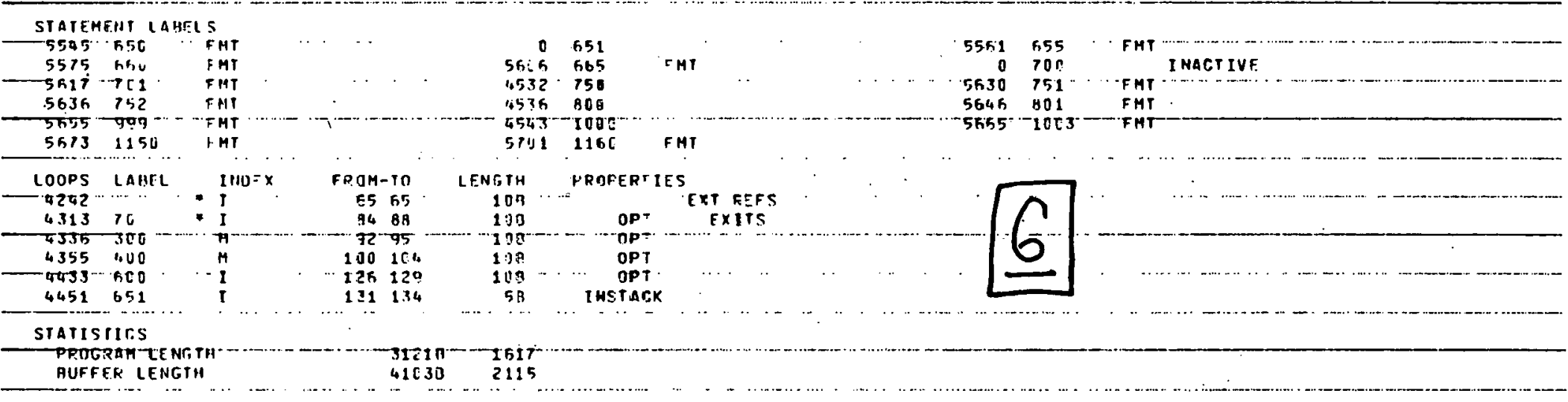


SURRC UTINF AITKEN

1C.174 OPT $=1$ TP.ACE

FTN $4.5+414$

$03 / 23 / 77 \quad 14.55 .20$

PAGE

1

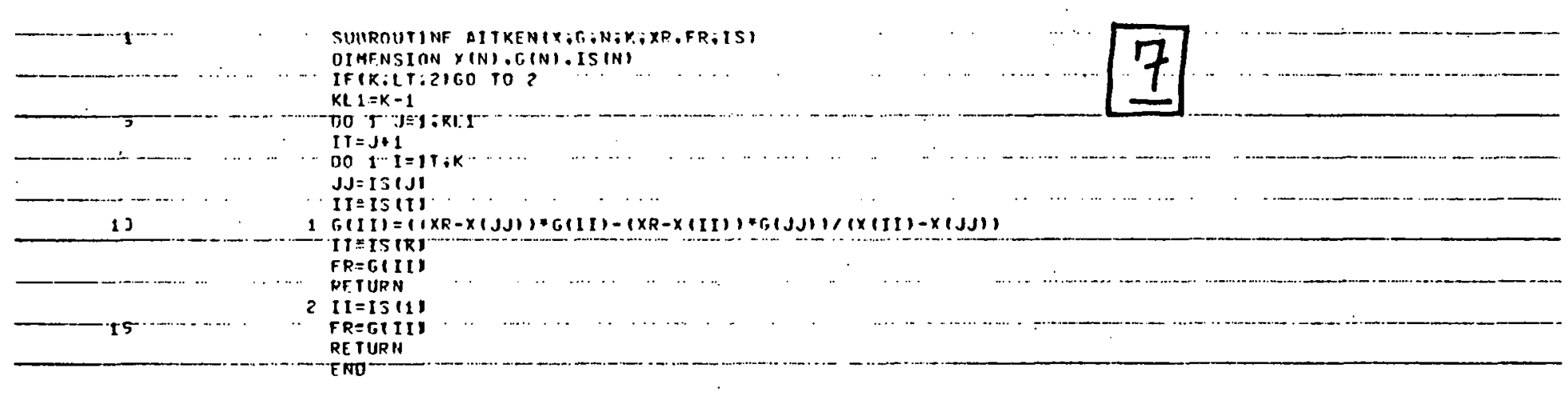

STHECLTC, RETE PENCE HAP-TREI)

- EmPRY OOTNTE:
3 AIIKEN

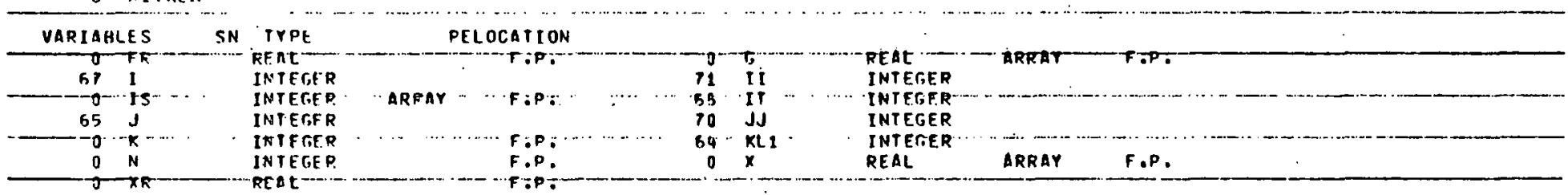

- STATEMEhT LaOELS 01

LOOPS LAOEL

INTEX FROM-TO LENGTH

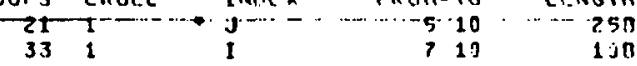

542

STATISTICS
PROGRAM 'EENGTH

11411
PROPERTIES

OPT NOT INNFR 
SUBPOUTIAF LTAIHT

14/7: OPT=1 TRACE

FTN $4.5+414$

$1.3 / 23177 \quad 14.55 \cdot 20$

PACF

1

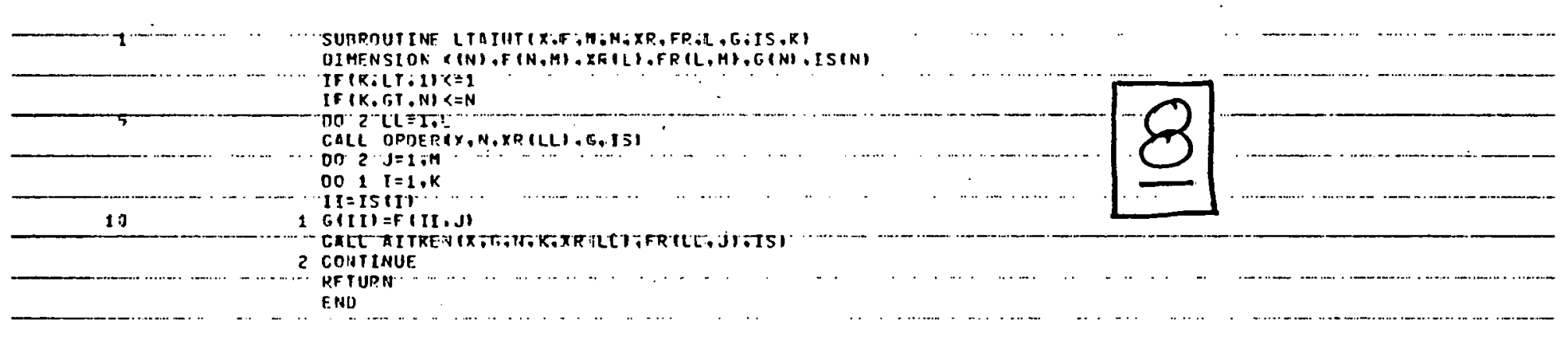

SYMBOLIC RFF RENCE MAP $(R=1)$

ENIRY POINTS

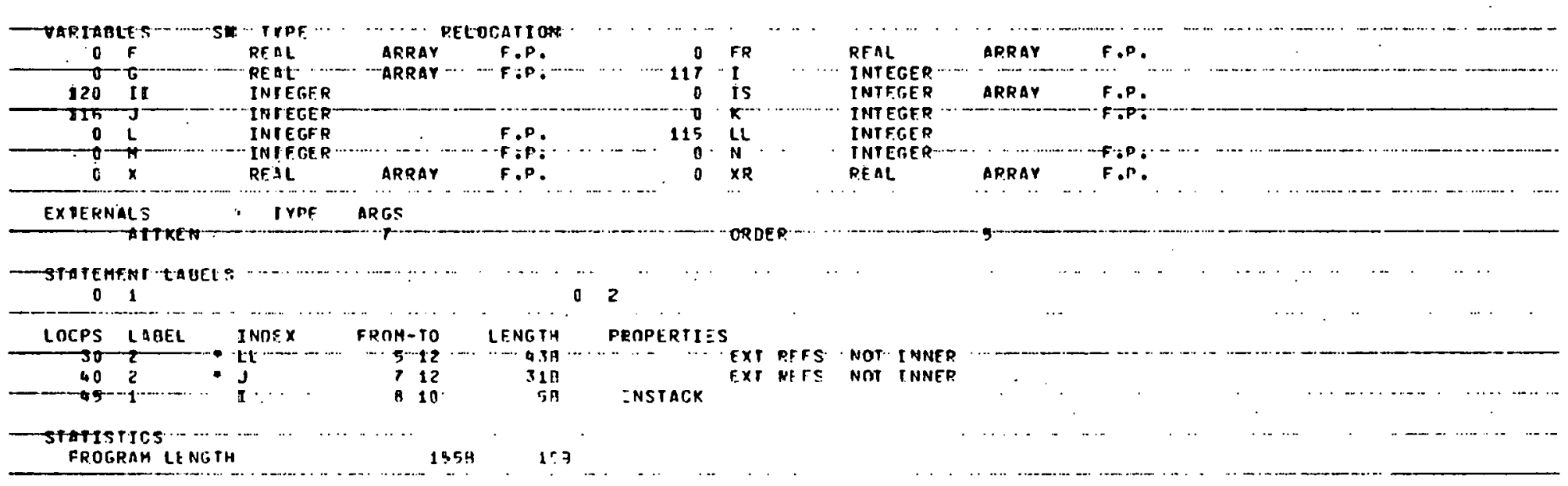




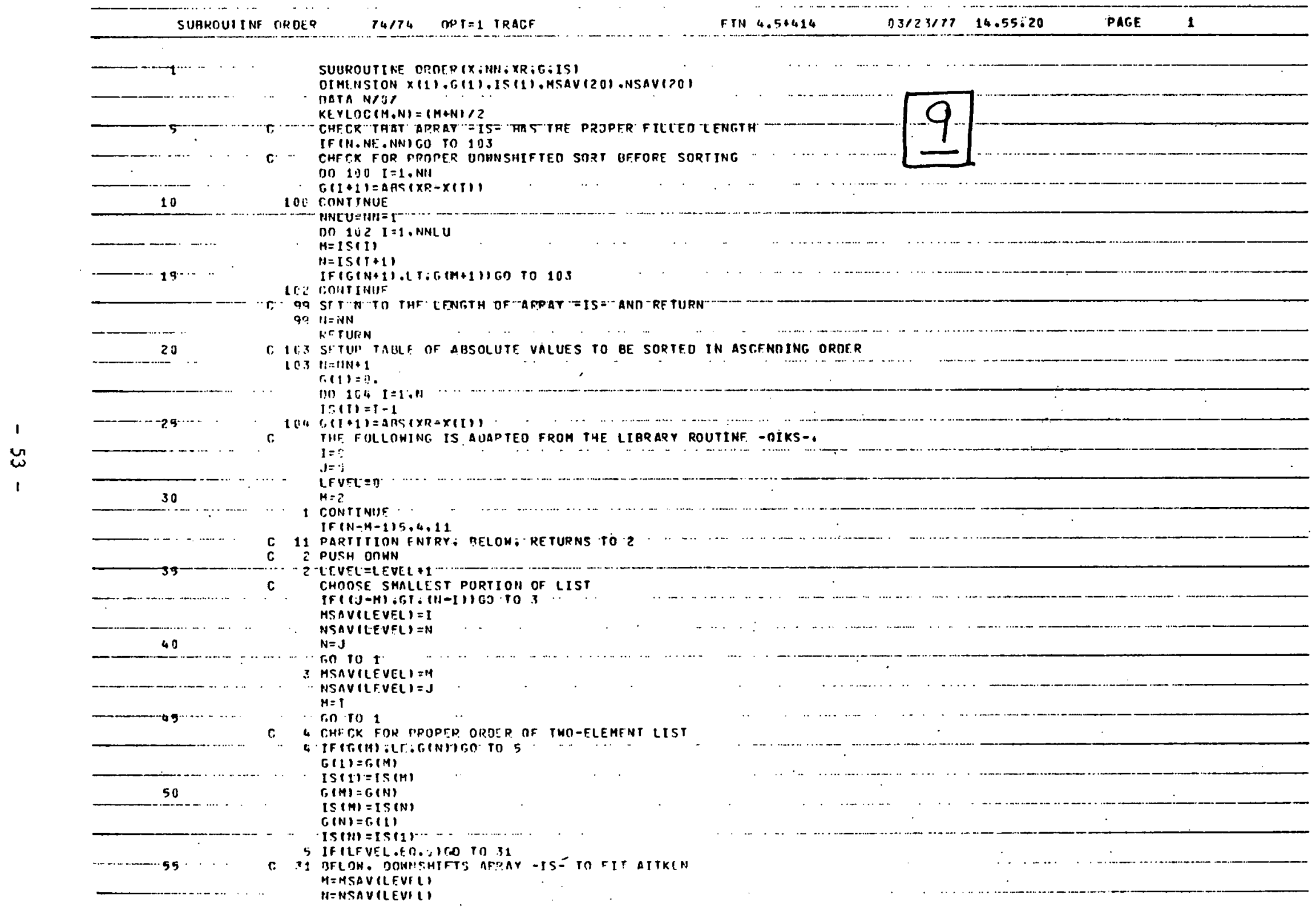


SUIROUTINE CLREP T4/7\% OPT 1 TRACE

F IN $4.5+414$

$03 / 23177 \quad 14.55 .20$

PAGE.

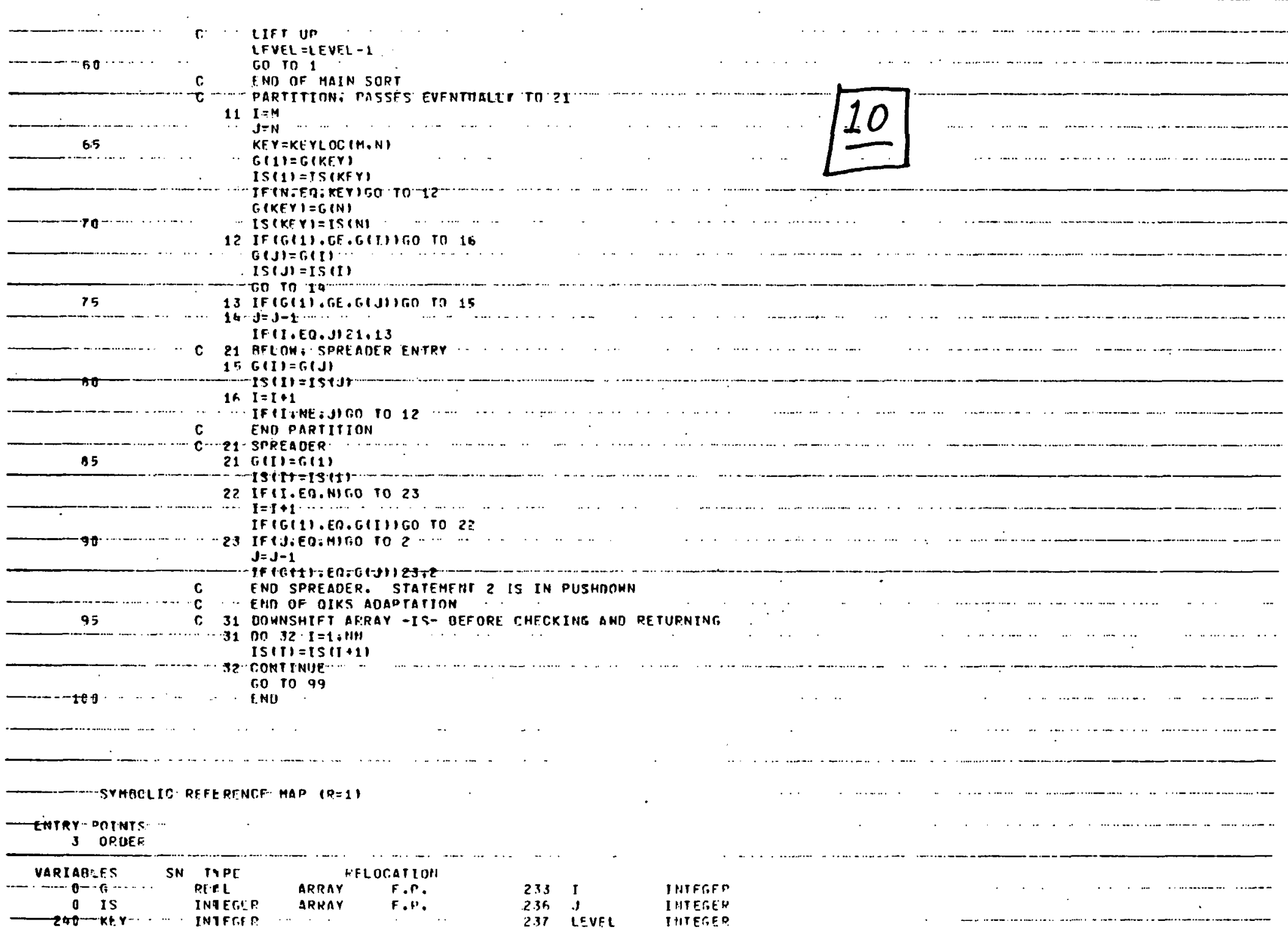




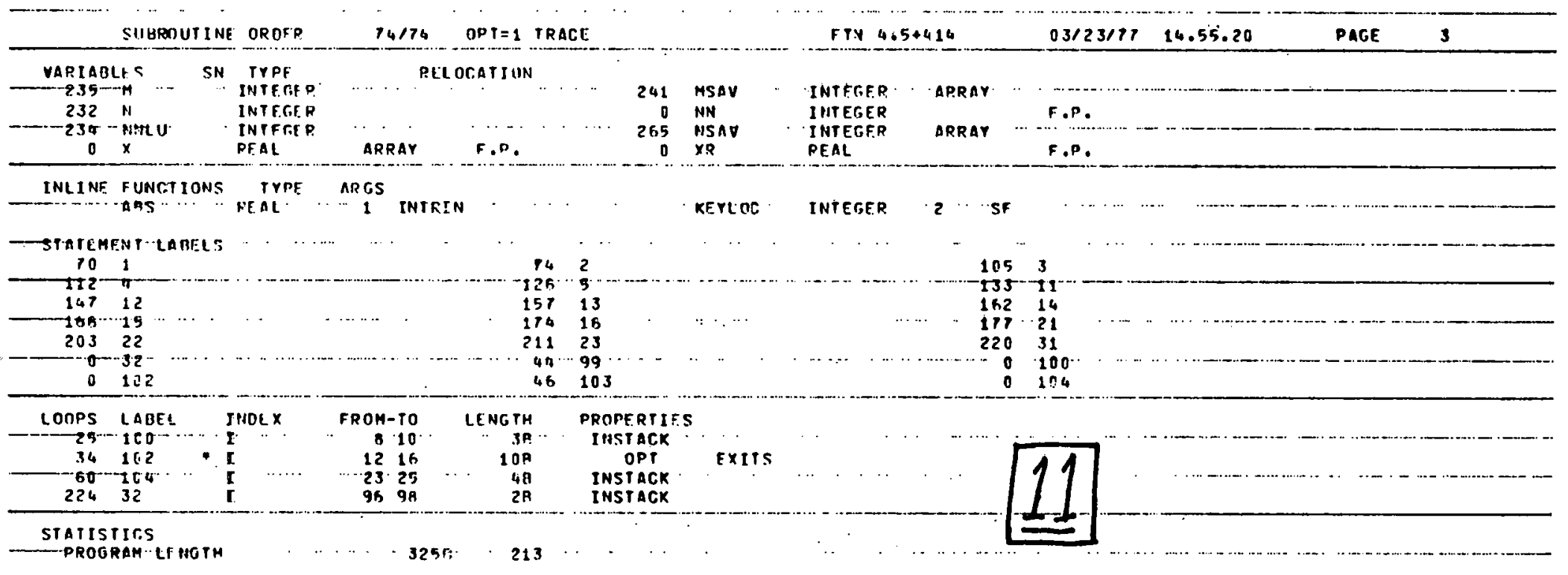




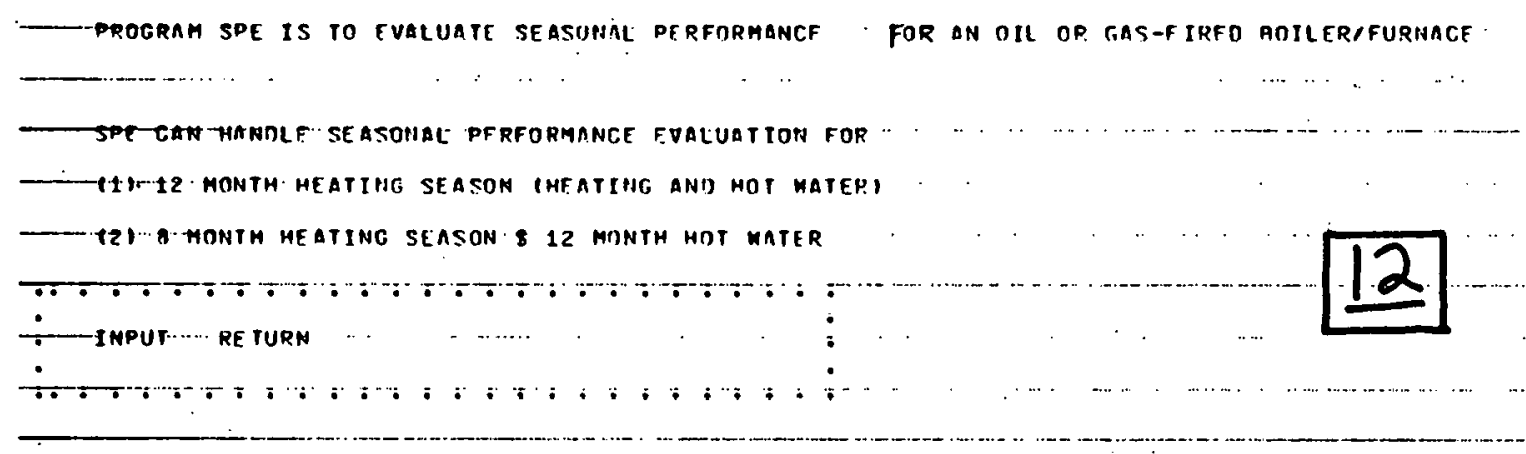

UHIT-HAME :-BOILER - [A]

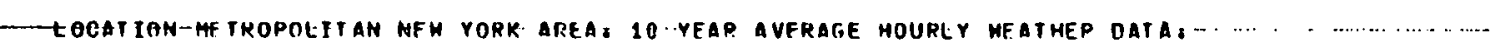

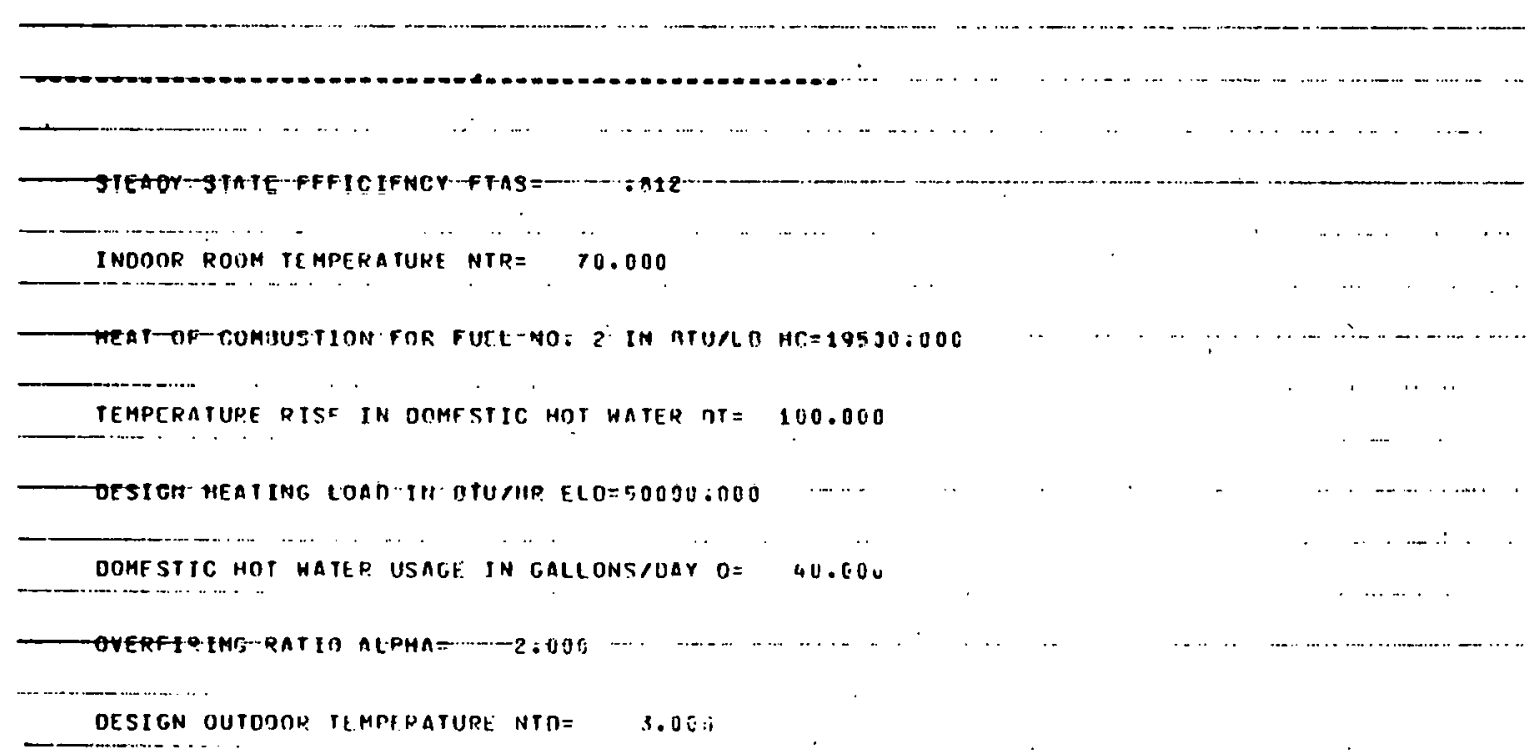




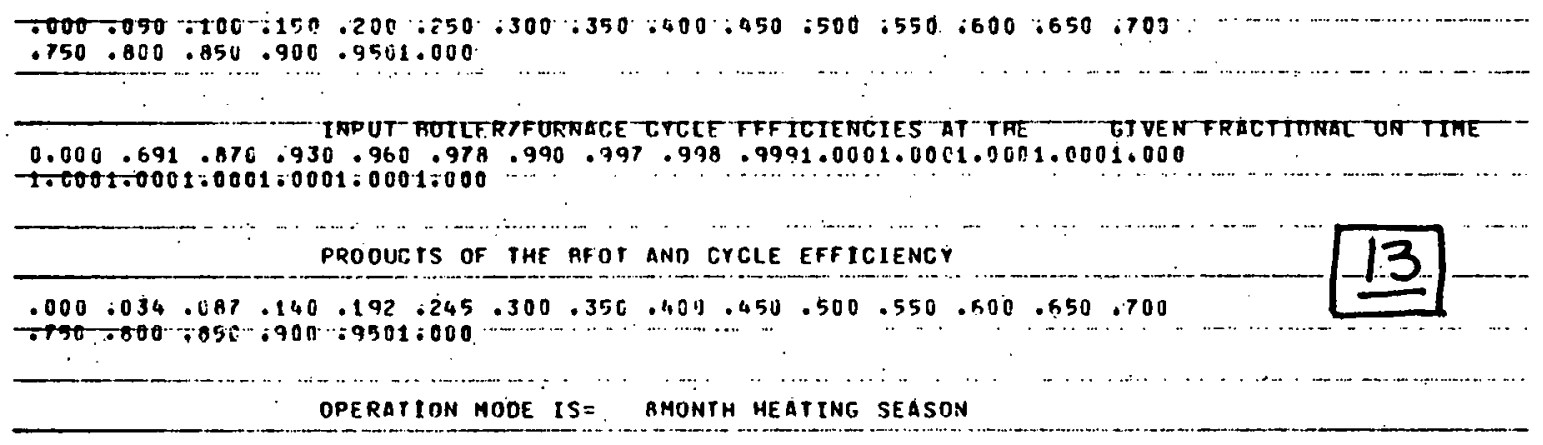

